\title{
Engaging Fringe Stakeholders in Business and Society Research Applying Visual Participatory Research Methods
}

McCarthy, Lauren; Muthuri, Judy N.

Document Version

Accepted author manuscript

Published in:

Business \& Society

DOI:

$10.1177 / 0007650316675610$

Publication date:

2018

License

Unspecified

Citation for published version (APA):

McCarthy, L., \& Muthuri, J. N. (2018). Engaging Fringe Stakeholders in Business and Society Research:

Applying Visual Participatory Research Methods. Business \& Society, 57(1), 131-173.

https://doi.org/10.1177/0007650316675610

Link to publication in CBS Research Portal

\section{General rights}

Copyright and moral rights for the publications made accessible in the public portal are retained by the authors and/or other copyright owners and it is a condition of accessing publications that users recognise and abide by the legal requirements associated with these rights.

Take down policy

If you believe that this document breaches copyright please contact us (research.lib@cbs.dk) providing details, and we will remove access to the work immediately and investigate your claim. 


\section{Engaging Fringe Stakeholders in Business and Society Research: Applying Visual Participatory Research Methods}

\section{Lauren McCarthy and Judy N. Muthuri}

Journal article (Post print version)

McCarthy, Lauren; Muthuri, Judy N, Engaging Fringe Stakeholders in Business and Society Research: Applying Visual Participatory Research Methods, Business \& Society, pp. 1-43.

Copyright () 2016 (The Authors). Reprinted by permission of SAGE Publications.

DOI: 10.1177/0007650316675610

Uploaded to Research@CBS: June २०17 


\title{
Engaging fringe stakeholders in business and society research:
}

\section{Applying visual participatory research methods}

\begin{abstract}
Business and society (B\&S) researchers, as well as practitioners, have been critiqued for ignoring those with less voice and power (e.g. women, non-literate or indigenous peoples) often referred to as 'fringe stakeholders'. Existing methods used in B\&S research often fail to address issues of meaningful participation, voice and power, especially in developing countries. In this article we stress the utility of visual participatory research (VPR) methods in B\&S research to fill this gap. Through a case study on engaging Ghanaian cocoa farmers on gender inequality issues we explore how VPR methods may be used by researchers to achieve more inclusive, and thus more credible, stakeholder research that can improve decision-making within businesses. Furthermore, we argue that ingrained social and environmental problems tackled by $\mathrm{B} \& \mathrm{~S}$ research and the unique context in which they occur may open up new opportunities to develop participatory visual methods for social change.
\end{abstract}

Keywords. Corporate Social Responsibility; Fringe Stakeholders; Drawing; Participatory Methods; Visual Methods. 
The central questions in this article are: who are considered stakeholders, and how are they engaged in corporate social responsibility (CSR) (Greenwood, 2007; Owen, Swift, \& Hunt, 2001) and business and society (B\&S) research more generally? We raise concerns over current $\mathrm{B} \& \mathrm{~S}$ research designs, pointing to three concepts that are particularly pressing for B\&S research: voice, participation and power. We suggest participatory and visual methodologies as a means of addressing some of these concerns, drawing on our own experience of using visual participatory research (VPR) methods in the Ghanaian cocoa value chain. 'VPR methods' is an umbrella term we give to research that incorporates participants who actively participate through drawing, photography, video-making or other visual methods ${ }^{1}$. We contend that B\&S research, much of which investigates CSR policies and programmes in developing countries across cultural, linguistic and conceptual differences, both requires innovative methodological approaches such as VPR methods, and provides new contexts in which to develop these.

Stakeholders, commonly defined as 'any group or individual who can affect, or is affected by, the achievement of the organization's objectives' (Freeman, 1984, p.46), have been positioned as central to B\&S research (de Bakker, Groenewegen, \& Den Hond, 2006), as they represent both the beneficiaries and implementers of CSR (Burchell \& Cook, 2006; Le Ber \& Branzei, 2010; Morsing \& Schultz, 2006). Research has thus focused on how businesses engage stakeholders, in the form of seeking opinions and gathering information, prior to designing and implementing CSR activities, and its implications for corporate and social/environmental outcomes (Pedersen, 2006; Rasche \& Esser, 2006). Research has also recommended the monitoring of CSR impact through stakeholder consultation during and following their implementation (Golob \& Podnar, 2014). Yet within B\&S research most attention has been paid to company stakeholders with the most salience, i.e. those individuals or groups with the most 
legitimacy, urgency and power (Mitchell, Agle, \& Wood, 1997) and the overwhelming focus in stakeholder theory and practice is on 'limiting and moderating' stakeholders (Mayes, Pini \& McDonald, 2012, p.843). Therefore which stakeholders are included and how they are engaged with in CSR research, as well as in practice, is important (de Bakker \& Den Hond, 2008; Mayes et al., 2012; Parent \& Deephouse, 2007). Critical scholars have called for the adoption of a bottom-up approach to $\mathrm{B} \& \mathrm{~S}$ research that allows for the voices of marginalised 'fringe' stakeholders (Hart \& Sharma, 2004) to help us better understand how CSR is received and enacted by stakeholders in ways which potentially aid, or exacerbate, societal problems (Banerjee, 2011; Idemudia, 2011). Frequently CSR scholarship explores 'wicked problems', such as inequality and climate change (Levin et al., 2012): ingrained, systemic and often takenfor-granted problems which span nations, organisations and governance systems, and increasingly include business as key players (Scherer \& Palazzo, 2011). In this article, we focus on one such problem: gender inequality.

Gender is a social construct, and can be understood as ingrained social practices which over time inscribe what it is to be a man or a woman into taken-for-granted 'truths' (West \& Zimmerman, 1987). Gender inequality exists in multiple forms and in every country across the world, but is particularly heightened in developing countries (World Bank, 2011), where women are less likely to have received an education and are more likely to experience discrimination, harassment and cultural barriers to participation in economic, social and political life (World Bank, 2011). Gendered practices thus exist within industries, across cultures, and are relevant to CSR programmes which ostensibly seek to promote equality (Grosser, 2009), including 'fair' trade (Barrientos, 2014; Smith, 2013). We thus consider women, especially those working within 
commodities production in developing countries, as 'fringe' stakeholders within many B\&S contexts.

Hart and Sharma (2004) define fringe stakeholders as those with less voice, power and urgency. As well as women in certain contexts, fringe stakeholders are: the extremely poor, weak and non-literate (Frynas, 2005; Hart \& Sharma, 2004; Jamali \& Sidani, 2011; Muthuri, 2007); the isolated or enslaved (Crane, 2013); indigenous peoples (Banerjee, 2011; Murphy \& Arenas, 2010), and other marginalised people (Le Ber \& Branzei, 2010). Their views may be ostensibly expressed through non-governmental organisations (NGOs) or community based organisations (CBOs) who act as their proxies (Jordan \& van Tuiji, 2006; Lang, 2012; Utting, 2007). Yet whether CSR initiatives designed to help poor and marginalised groups in developing countries actually deliver on these aims, and how researchers treat the roles of power, class, ethnicity and gender in mediating such interventions continue to be questioned (Blowfield \& Dolan, 2008; Khan, Munir, \& Willmott, 2007; Khan \& Lund-Thomsen, 2011; Prieto-Carrón, Lund-Thomsen, Chan, Muro, \& Bhushan, 2006; Utting, 2007). One means of scrutinising CSR practice is by reappraising $\mathrm{B} \& \mathrm{~S}$ research methods, which we argue may not always pay full attention to fringe stakeholders in terms of ensuring their meaningful participation, enabling their 'voice', and challenging power relations.

In this article we propose VPR methods as a response to the inconsistencies in traditional methods in B\&S research (Banerjee, 2011; Mayes et al., 2012), particularly when researching fringe stakeholders in unique contexts facing complex social problems (Höllerer, Jancsary, Meyer, \& Vettori, 2013; Thatchenkery, Avital \& Cooperrider, 2010). We first expand on current approaches to $\mathrm{B} \& \mathrm{~S}$ research and highlight how methods which are non-participatory and rely exclusively on the verbal may underplay the importance of meaningful participation, voice and 
power in the research process. We then introduce visual methods to B\&S research. Reflecting on a case study researching gender in the Ghanaian cocoa value chain, we argue that VPR methods can aid meaningful participation of fringe stakeholders, support their voice in the research process, and begin to address the power imbalance between researcher and participants (Mayoux $\&$ Chambers, 2005). This article thus contributes to the call for more innovative and creative ways of generating and handling qualitative data in management studies (Bansal \& Corley, 2011), and particularly in B\&S research (Prieto-Carrón et al., 2006). It also demonstrates how the unique context of, and ingrained social and environmental problems tackled by, B\&S research open up opportunities to further develop visual methods for social change.

\section{Fringe Stakeholders and B\&S Research Methods}

B\&S research remains dominated by quantitative methods and research designs, reflective of management literature more generally (Lockett, Moon, \& Visser, 2006). In a systematic review of top management and B\&S journals, Lockett et al. (2006) found that only 20 per cent of all empirical papers utilised qualitative methods. Similarly, an updated review of 588 CSR journal articles and 108 books and book chapters found only 11 per cent contained qualitative empirical research (Aguinis \& Glavas, 2012). When qualitative methods are used, 'traditional' methods such as interviews, followed by observations, remain dominant (Bansal \& Corley, 2011; Taneja, Taneja, \& Gupta, 2011). We note the conspicuous under-utilisation of participatory (Bansal \& Corley, 2011; Touboulic \& Walker, 2016) and visual (Höllerer et al., 2013) methodologies within B\&S research. In the paragraphs below we explain how the concepts of participation, voice and power are particularly salient to B\&S research, and how VPR methods thus far applied 
in other disciplines may contribute to how we work with fringe stakeholders in research and practice.

First, whilst recognition of the value of including fringe stakeholders in business research is building (Hart \& Sharma, 2004), actually contacting them is often challenging, especially across different cultures (Burns et al., 2014). For example, in many regions, women are denied access to data collection events, or are restricted from speaking (Gujit \& Kaul Shah, 1998). Further, these individuals are not often accessed for long periods of observation, nor are the contexts always ethically desirable for researchers to do so. Interviews may work well, but issues of power within the research relationship, language difficulties or concept confusion all contribute to a problematic research design. The costs, however, of ignoring fringe stakeholders can be high for both CSR implementers and for B\&S researchers who attempt to assess the value of CSR for stakeholders, businesses and the wider environment.

We further argue against simply taking on face value the inclusion of fringe stakeholders such as women into $\mathrm{B} \& \mathrm{~S}$ initiatives as equivalent to meaningful participation and inclusion (Cornwall, 1998; Jackson, 2012). For example, women are the focus of many Base of the Pyramid (BoP) and microfinance initiatives in the developing world (Prahalad and Hammond, 2002), which would suggest a movement towards gender equality. Yet evidence for the voice and agency of women within these CSR efforts is debated (Dolan, Johnstone-Lewis and Scott, 2012; Karnani, 2007). Thekuddan and Thandon (2009), evaluating Unilever's Project Shakti, found that men often took over women's micro-businesses and Tornhill (forthcoming) critiques Coca-Cola's 5by20 BoP programme for neglecting to consult with women stakeholders about their own needs. Thus there is a need for B\&S researchers to question the inclusion of fringe 
stakeholders in CSR practice by considering how to include silenced, over-looked or recalcitrant voices within our own research.

Participation can be understood as a continuum of inclusion and involvement within research (Reed, 2008), moving from passive engagement to active citizenship of stakeholders (Arnstein, 1969). Rooted ontologically in social constructionism and interpretive epistemologies (Ladkin, 2004), participatory methodologies see participants as co-constructers of social phenomena under study, through the everyday practices they perform (Berger \& Luckmann, 1967; Giddens, 1984). Participants are thus the 'agents rather than objects of research' (Chambers, 1997, p.12). For B\&S researchers, participatory methods could better access fringe stakeholders' experiences and sense-making, especially in cultural contexts that differ from the researchers' (Chambers, 1997; Crawley, 1998; Gaventa \& Cornwall, 2001; Mayoux \& Chambers, 2005). This is especially pertinent when studying ingrained social practices (such as gender (West \& Zimmerman, 1987)) in organisations, which are dynamic, temporal and multisensory (Höllerer et al., 2013; Küpers, 2014).

Participatory B\&S research would involve first including a wider range of stakeholders over and above those easiest to reach, most amiable, or most powerful in any given community (Chambers, 1997; Mohan, 2001). At the lower end of the scale, research on CSR programmes is often carried out through workers' group leaders, trade union representatives, NGOs or simply in discussion with a manager (Lang, 2012; O'Rourke, 2002). Filtering fringe stakeholders' experience through others can be misleading (Auret \& Barrientos, 2004) or limits the extent to which stakeholder engagement creates meaningful dialogue (de Bakker \& Den Hond, 2008; Mayes et al., 2012; Murphy \& Arenas, 2010; Utting, 2007). For B\&S researchers, the question of how then to involve fringe stakeholders may provoke various responses. Some participant action 
research (PAR) approaches include participants throughout the research process, including the development of the research design, whereas other approaches such as 'cooperative enquiry' may only involve stakeholders in the data generation portion of research (Reason, 1994). Further, some participatory approaches explicitly aim to 'empower' or 'emancipate' participants (especially in action research), whereas others have a more 'functional' design which seeks to obtain useful information from fringe stakeholders in an arguably less biased (Reed, 2008) or exclusionary manner than mainstream research methods (see Chambers, 1997 for a critique of surveys). B\&S research on stakeholders may be descriptive, normative or instrumental (Donaldson \& Preston, 1995) and thus may engage with fringe stakeholders along varying degrees. Yet we would argue that the interpretive, reflexive nature of VPR methods requires engagement based less as one-way communication and more as a two-way process (Chambers, 1997; Reed, 2008). Meaningful participation would entail participants being able to speak out about business' influence in their lives during the research process, perhaps enabling them to influence CSR decision-making and outcomes, which more broadly could enable transformative social change that benefits fringe stakeholders, through involvement with research and practice (Mohan, 2001).

Second, and relatedly, 'voice' is a key construct in organisational theory yet it is underconceptualised within B\&S research (Le Ber \& Branzei, 2010). Voice relates to agency (Hirschmann, 1970); it is 'about speaking, not just being spoken about' (Wray-Bliss, 2003, p.2 in Warren, 2005, p.869). Le Ber and Branzei (2010) outline how within practice stakeholders can be 'voice-receiving' (under-utilising their views), 'voice-making' (engaging in mutual dialogue), and 'voice-taking' (stakeholders take control of speech in order to make societal changes). We posit that these categories could easily be applied to B\&S research too, where experience with 
the second two approaches to stakeholder research is limited (Mayes et al., 2012). VPR methods have long been positioned as one means of facilitating voice, as they are both 'participatory', and through the 'visual', contribute to an expansive notion of voice (Warren, 2005). Voice can thus be understood as expression and 'the right or opportunity to express a choice or opinion' (Warren, 2005, p.870), in ways that supplement words and connect deeply to emotion and indescribable feeling (Barthes, 1981; Meyer, 1991). In order to better understand phenomena such as CSR it follows that fringe stakeholders' 'voices' should be enabled within B\&S research, but we expand the concept beyond the vocal to the visual (Warren, 2005). Facilitation of 'voice' in multiple registers is particularly important when talking about sensitive or emotional topics (Bryans \& Mavin, 2006; Kearney \& Hyle, 2004), which are replete within B\&S research, incorporating themes of inequalities and exploitation, amongst others. Furthermore, in contexts such as developing countries, certain fringe stakeholders may be denied a voice by societal norms, often along gender lines (Jackson, 2012). Here, employing interviews or observation may often miss out the most vulnerable and their potential input into research.

Third, and tying together participation and voice, consideration of power relations is particularly important in $\mathrm{B} \& \mathrm{~S}$ research, due not just to the topics under study, but to the unique contexts in which such research may take place. We define power as 'an attribute growing from within oneself' (Gaventa \& Cornwall, 2008, p.72), since we pay attention to the agency and potential 'empowerment' of participants within CSR research (Rowlands, 1997). That said, we also recognise how power, understood as individuals' 'transformative capacities' (Giddens, 1984), can be stifled or misdirected by others, such as in a research setting. Traditional research methods (such as surveys or structured interviews) may not always be sensitive to local power relations, especially in developing countries 'where factors such as language, culture, education 
and pluralistic values can all affect the process of negotiation and decision-making' (Blowfield \& Frynas, 2005, p.507). For example, indigenous peoples have been silenced in stakeholder consultations (Banerjee, 2011; Castleden, Garvin, \& First Nation, 2008; Murphy \& Arenas, 2010). These intersectional power relations (Banerjee, 2011) are unheeded by B\&S researchers when they assume that talking to 'the community', trade union representatives (Utting, 2007) or an NGO as proxy (Murphy \& Arenas, 2010; Lang, 2012) is tantamount to engagement.

Although B\&S researchers can employ local interpreters to bridge communication barriers, as well as carry themselves in a culturally and politically sensitive manner so as to 'belong' (Liamputtong, 2009), the power distance created by socio-cultural differences can be great, limiting the ability to understand the lived experiences and unique perspectives of those under study. As CSR often stands accused of doing little to challenge power inequalities between fringe stakeholders and corporate elites (Banerjee, 2011; Mayes et al., 2013; Utting, 2007), perhaps one attempt to bridge this gap in scholarly research could be through methodologies that acknowledge and reduce the power distance both between researcher and participants (Gaventa \& Cornwall, 2001; Mayoux \& Chambers, 2005) and perhaps within systems of inequality more generally (Crawley, 1998; Mayoux, 2012). We critically discuss in depth within the remainder of the article whether and how VPR methods applied to B\&S research can achieve this. However, mindful of our focus on the 'participatory' element of VPR methods thus far, in the next section we elaborate further on the 'visual', before introducing our own experience of using VPR methods in Ghana.

\section{Applying the Visual to Business and Society Research}


Whilst on one hand the visual has a long history in global human development (Gombrich, 1982; Pink, 2001), it seems as if the $20^{\text {th }}$ and $21^{\text {st }}$ centuries are characterised by images and the aesthetic (Baudrillard, 1983). Correspondingly a 'visual' or 'pictorial' turn (Mitchell, 1994) has taken place in the humanities and social sciences (Bell \& Davison, 2013; Pink, 2001). From analysis of artwork, advertisements, maps, photographs and visual artefacts (such as posters, tapestries or films), images proliferate in 'traditional' visual disciplines such as art history (Berger, 1972), and into philosophy (Barthes, 1993; Baudrillard, 1983), geography (Rose, 2003), psychology (Gombrich, 1982), anthropology (Bates \& Mead, 1942; Pink, 2001), sociology (Foucault, 1973; Goffman, 1979) and organisation studies (Bell \& Davison, 2013; Davison, McLean \& Warren, 2012; Meyer, 1991; Vince \& Broussine, 1996; Zuboff, 1988). Attention to the visual in social sciences has arisen alongside interpretivist approaches to research and philosophy, driven by a view of the world, and human meaning and interaction, as socially constructed (Berger \& Luckmann, 1967). The visual, as both artefacts of, and ways into, understanding socially constructed practices, has thus become a popular vehicle for social science researchers. It communicates richly and deeply the subjective human experience (Spencer, 2011). The visual does not just capture snapshots of society, then, but is in itself continuously socially constructed, deconstructed and imbued with power relations, necessitating a reflexive position on the part of the researcher (Rose, 2003).

The 'visual turn' within organisation studies (Davison et al., 2012; Meyer, Höllerer, Jancsary, \& van Leeuwen, 2013) provides new methodologies (Höllerer et al., 2013) required by the accompanying 'practice turn' which seeks to explore organisational processes, including CSR (Rasche, de Bakker \& Moon, 2013), as they unfold (Rasche \& Chia, 2009). Organisations are sites of visible, everyday practice, e.g. family photographs on colleagues' desks, head-office 
artworks, work attire, annual report imagery, logos, branding and office design (Bell \& Davison, 2013; Vince \& Broussine, 1996). The visual can also capture abstract, ongoing practices related to identity and emotions, as seen in studies of office space (Warren, 2005), identity (Shortt \& Warren, 2012) and leadership (Guthey \& Jackson, 2005). Pertinent to our focus on gender, there is also a rich history of visual analysis in gender and feminist organisational studies (Bell \& Davison, 2013), often highlighting how inequalities between genders are symbolised within images in advertisements (e.g. Borgerson \& Schroeder, 2002; Goffman, 1979) and corporate documents (e.g. Benschop \& Meihuizen, 2002).

The use of visual methods, however, has not been matched in the field of B\&S research (Aguinis \& Glavas, 2012; Bansal \& Corley, 2011; Taneja et al., 2011). Of the few studies which have adopted visual methods, they have explored pre-existing images, such as the photographic representation of CSR in reports and websites (Höllerer et al., 2013; Rämö, 2011) and of various stakeholders, either in advertising (Borgerson \& Schroder, 2002) or their experiences of corporate disasters such as Bhopal (Matilal and Höpfl, 2009). Warren (2005), however, identifies three other approaches to the visual, beyond analysing existing images, which we believe are pertinent to B\&S research:

(1) Studies that record events using photography or video;

(2) Studies that use images to provoke a response within interviews, commonly described as photo-elicitation; and

(3) Studies that enable participants to produce their own images.

We concentrate on (3) within this article, since we argue for using visual methods in a participatory approach alongside, rather than on, fringe stakeholders (Reason, 1994; Vince \& 
Broussine, 1996). Participant-led visual methods are frequently used in development research (Narayanasamy, 2009), with drawing commonly used with fringe stakeholders such as smallholder farmers in developing countries. They are also used extensively in healthcare, social work and education research because of the innovation required to find other ways of communicating beyond, or in addition to, the verbal (Vince \& Warren, 2012). For example, children have made videos on the environment (Gauntlett, 1996); teenage mothers in South Africa have photographed their experiences (Liebenberg, 2009); Chinese female farmers have recorded their health concerns on pesticides through photography (Wang, 1999); Ghanaian farmers have photographed their progress with training and development (PhotoVoice, 2015); and refugee women have told their story through photography (O'Neill, 2008). Notably, these studies aim to influence policy and practice by remaining as close as possible to participants' meaning and experience (PhotoVoice, 2015).

We further focus in this article on 'participant-produced drawing' (Kearney \& Hyle, 2004), or a 'freehand sketch' (Meyer, 1991), which while garnering more attention remains, according to Stiles (2013), a method rarely used within organisation studies (excepting Broussine \& Vince, 1998; Bryans \& Mavin, 2006; Kearney \& Hyle, 2004; Meyer, 1991; Stiles, 2004; 2011; Vince \& Broussine, 1996; Zuboff, 1998). Drawing, it is argued, is a meditative process that allows for reflection on feelings and emotions: indeed it is one of the oldest forms of human communication (Gombrich, 1982; Stiles, 2013). We demonstrate the case for the visual, alongside the verbal (Küpers, 2014; Warren, 2005), by exploring our own experience of using a particular form of VPR: the Gender Action Learning System (GALS) in research with fair trade farmers in Ghana. 


\section{Exploring gender and power in Business \& Society Research: A Ghanaian Case Study}

Our case study sought to understand gendered power relations along occupational and domestic divisions of labour in the Ghanaian fair trade cocoa value chain through VPR methods. We first introduce the research problem, before briefly outlining the specific VPR method we adopted, called the Gender Action Learning System (GALS). In the interests of brevity, a step-by-step guide on how to emulate this method is included in Appendices 1 and 2. We then discuss the ways in which GALS demonstrates how VPR approaches can help attend to problems of power, voice and meaningful participation in $\mathrm{B} \& \mathrm{~S}$ research and practice.

\section{The Research Problem}

Although in some regions Ghanaian women are afforded more freedom than women in other Sub-Saharan African countries (Clark, 1995), they still face inequalities in terms of access to farming resources such as loans, training, services and access to cooperatives, which would enable them to join initiatives such as Fairtrade (Barrientos, 2014; Capelle, 2009). In response, a fair trade UK confectionary company, their Ghanaian cocoa cooperative supplier, and an NGO partner together developed a 'Gender CSR programme', to both bring female 'fringe' farmers into the cooperative, and to boost their incomes. Women received leadership training, alternative income training (e.g. making soap or batik to sell), microfinance and support through peer groups. We became involved in 2013 in the course of the programme evaluation. Our research questions were: What are the roles of men and women in the cocoa value chain? How does the gender programme aid equality? 
Many of the farmers, especially the women, were extremely poor, lived far from towns and had little to no formal education. According to the supplier, previous research attempts had therefore been somewhat hampered by the dominance of men in discussions, and participants were reticent to talk about sensitive issues (Personal Communication with Gender Officer, March 2013). Furthermore, when husbands or family members were present, women would often defer to their opinion, or let them speak on their behalf. Accordingly, issues of power, voice and context had to be planned for in our research design.

\section{The Research Design}

Our key objectives were to: (i) understand the roles of men and women 'fringe' stakeholder cocoa farmers at home and on the farm, by analysing their tasks, decision-making, and asset ownership; and (ii) evaluate the success of the programme along economic, social and political empowerment dimensions. These are widely considered to be reliable indicators of equality in a value chain context (UNECA, 2011). Crucially, work outside direct cocoa production was included in our design, since value chain analyses often ignore so-called unproductive work which has previously contributed to the gender-blindness of B\&S value chain research (Auret \& Barrientos, 2004; Mayoux, 2010; Riisgaard, Escobar Fibla, \& Ponte, 2010). Joined by a translator and supplier representative, the first author visited four villages in two regions and ran four participatory workshops with 48 cocoa farmers, producing 48 drawings as well as verbal data from discussion groups (Table 1). 
Table 1 Goes About Here

GALS, one form of VPR method among many, was developed by Dr. Linda Mayoux and is theoretically grounded in participatory approaches to social research in value chains (e.g. Auret and Barrientos, 2004), group action research informed by Friere's Community Conscientisation theory (Freire, 1970) and participatory development techniques (Chambers, 1997; Mohan, 2001). It has been adopted by a wide range of development agencies (Farnworth, 2011; TWIN, 2013; Mayoux \& Mackie, 2007) and published in academic journals (Butler, 2014; Mayoux, 2010; Mayoux, 2012; Mayoux \& ANANDI, 2005).

GALS includes drawing and discussion in workshops (Mayoux, 2010). Since our particular concern was around gender, power and work in the cocoa value chain, GALS offered a specific creative approach to the problem of researching 'gender' in cultural contexts very different to our own (Mayoux \& ANANDI, 2005). Since simple symbols are used as a means to visually represent gendered divisions of labour and ownership, GALS offered a route into answering our research questions that translated difficult concepts such as gender (of which there is no word in Twi, the local language) across linguistic and cultural barriers. We briefly outline the research steps below (planning and reflections are included in Appendix 1).

Step one: The drawings. In the first drawing exercise we asked participants to draw their household and circle the primary decision maker (Figure 1). The household drawing enabled a snapshot of each participant's home situation (married, widowed etc.) and generated initial data on decision-making (an indicator of power) in the home. This also introduced participants to 
working with pen and paper, and led to lots of laughter and discussion, thus easing everyone into the rest of the workshop.

\section{Figure 1: Goes About Here}

The second, and main, exercise was drawing a 'gender tree' (Figure 2). The tree symbol is used in GALS as testing in various countries has demonstrated how it is an easily understandable metaphor that mirrors the process of cocoa farming and economic production (from roots to fruits) (Mayoux, 2010).

Figure 2: Goes About Here

Participants drew their individual drawings whilst the first author drew their own 'gender tree' on a large flipchart, explaining the process step-by-step through a translator when necessary. First, we drew a simple tree outline: roots, trunk and branches. Then, throughout the workshop participants drew symbols either:

- On the left hand side of the tree, indicating women's work/expenditure or ownership;

- In the middle, indicating shared work/expenditure or ownership;

- On the right hand side, indicating men's work/expenditure or ownership. 
At the roots, symbols represented 'cocoa work', 'other paid work' and 'unpaid work', since the research aimed to explore the gendered divisions of labour in multiple dimensions. The suitability of symbols had been discussed before the workshops with local supplier staff (many of whom came from farming backgrounds) who had daily contact with farmers (Appendix 3 shows our original hand-drawn symbols). In the original conceptualisation of GALS (Mayoux \& Mackie, 2007) participants are given more time to come up with their own symbols, but given time constraints and experience in other locations, we shortened the process by suggesting symbols at the workshop. Participants, however, were also encouraged to create symbols of their own. On the 'branches' of the tree we drew the 'fruits' of work, items which were purchased, in symbol form e.g. a bicycle. This answered questions on who received and made decisions on income, giving an indication of economic freedom. Finally, participants drew symbols for assets: housing, money and land, relevant to their own household situation. For example, a picture of a farm drawn on the right-hand side of the tree-trunk indicated that the man owned the land.

After individuals completed their trees, a short break was taken before reconvening for group discussions. Individuals were encouraged to keep their own trees, and the pens, and some communities kept the master trees and displayed them in a communal area (Personal communication with supplier staff, June 2013). Photographs were taken of each tree, and their corresponding household diagrams, for later analysis.

Step two: Discussing in groups. Following the drawing activities, participants were split into male and female groups, with the aim that this would enable participants to speak more openly about their drawings and experiences (Morgan, 1997), especially pertinent to many developing countries where women are afforded much less agency (Jackson, 2012). Each group was given a same-sex facilitator as well as a translator. Our questions were focused yet open 
enough to allow elaboration (Morgan, 1997), and sought answers pertaining to women and men's roles and experiences in the value chain, as well as their perception of, and wishes for, the gender programme:

1. Is the tree balanced?

2. What can women do to help balance the tree?

3. What can men do?

4. How has the cooperative [real name] helped balance the tree?

5. What could they do in the future?

After approximately 30 minutes the groups discussed their answers in plenary. We videorecorded the discussion to analyse the verbal data later. We used the discussion to generate verbal data, as participants used the trees to illustrate their points. We also were able at the end of the plenary to ask participants what they thought of the workshop, in order to capture both the substantive and processual elements of drawing the 'gender tree'.

Step three: Analysis. Photos of the images and videos were uploaded into the NVivo10 media function. Household drawings were thematically analysed (e.g. how many women were circled as decision-makers; how many children were drawn in each household on average). The trees were analysed using visual content analysis steps (Bell \& Davison, 2013). Bell (2001) argues that validity in visual methods is achieved when there is a close fit between theory and concepts, and inferences from the visual data. Thus it is important that any analytical framework (we use our symbol key, Appendix 3) is grounded in theory (we based our measurement of gender roles, ownership \& expenditure, and their concurrent symbols, on established development frameworks e.g. UNECA, 2010). Reliability is ensured by a/ having a discrete 
matrix of variables and values (Bell, 2001), which are b/ exhaustive (i.e. all symbols were counted and coded) and c/ exclusive (each symbol related to only one value) (Rose, 2012). Using our symbol key as a discrete coding matrix, symbols on each tree were coded for different work, expenditure and ownership by gender onto an SPSS spreadsheet. We ran simple descriptive analytics to produce frequencies and correlations. This is a very traditional manner of analysing visual material, akin to coding advertisements or corporate reports (see Benschop \& Meiheizen 2002 for a good account of this). There is no one accepted criteria for VPR analysis (Vince \& Warren, 2012): thus outputs could be analysed in a more interpretive manner (Pink, 2001), which we reflect on in our concluding remarks.

Understanding gender in value chains requires both quantitative data (i.e. numbers of female landowners) as well as qualitative data (drawn from observations of women's opportunity to engage in conversation, focus group verbal data, and visual evidence of decision-making in the household diagrams). Both verbal and visual data were supplemented with interviews with 23 organisational members, as well as with existing secondary literature. We would suggest that high quality VPR requires systematic analysis of visual data, supplemented with verbal and textual evidence too (Meyer, 1991). Taken altogether these multiple data sources form the basis of a thematic analysis common in qualitative research, as initial codes (seen visually and heard verbally, and framed by secondary literature) were collated into themes and then into more abstract concepts (Table 2), providing credible, valid findings. More detail on the overall analysis, including challenges, can be found in Appendix 2.

Table 2: Goes About Here 


\section{Voice, Power and Participation through VPR Methods}

Drawing on the case study described above we reflect to what extent VPR methods help: (a) aid meaningful participation, particularly of business' fringe stakeholders; (b) facilitate stakeholder 'voice'; and (c) raise awareness of, and potentially readdress power imbalances in research. To contextualise this discussion, we first give a brief overview of the findings of our GALS case study.

\section{What GALS found}

The gender tree drawings primarily collected descriptive data about the gendered division of labour on the cocoa farm, in supplementary work, and in domestic work (Table 3). Coding the symbols revealed that men and women largely perform separate work roles. Men tend to perform the 'heavier' or more 'dangerous' roles, such as bagging and weighing cocoa or clearing land (Fig.3). These tasks are crucial for economic reasons, since to be able to weigh cocoa (as a purchaser) brings extra income and status, and clearing land is indicative of owning that land. Yet when asked in discussions farmers said that it was 'unnatural' for women to do these tasks, despite evidence that women could use equipment or acquire help to perform these tasks, if given the chance. This demonstrates how opportunities for women are limited due to social norms and a strong cultural emphasis on women as a domestic subject i.e. a mother. Table 2 in the previous section helps outline the sources of data and analytical steps we took to come to conclusions such as these. 


\section{Table 3: Goes About Here}

In terms of asset ownership, a key indicator of social and economic empowerment, the GALS drawings demonstrated that men dominate ownership of land, housing and money access (Table 4). In terms of political involvement in the cooperative, the drawings showed that a significant number of households had both male and female cooperative members, suggesting men had gifted a portion of farming land to their female relatives in order for them to be members in their own right. This is because women must be landowners to become cooperativemembers, and membership leads to voting rights, extra income and access to CSR training. This was tentatively linked to the gender programme, but more evidence was necessary to verify this claim.

Table 4: Goes About Here

Social empowerment entails fostering self-confidence and freedoms for human flourishing (Cornwall, 2014). Women's decision-making capability was captured in the household drawings, with 77 per cent of mixed households circling the male as the decisionmaker (Fig.1). Yet the tree drawings showed women's independence in other ways: they had separate lives from men in terms of economic roles and expenditure (Table 4; Fig.4). This is common within Ghanaian culture, where 'individuation' is an important value for men and 
women (Clark, 1995, p.107). The GALS drawings, however, also showed that women had limited freedoms due to their overwhelming responsibility for domestic duties (Table 4; Fig.2). In the smaller communities, where women were further from resources such as clean water, women's time was largely spent on domestic work, leaving little time to invest in cocoa farming, other work, or any activities of the gender CSR programmes. Discussions revealed that although both men and women were aware of this 'double-work' burden (Men's Group Discussion), women's 'naturalised' role as the main meal providers and housekeepers was one reason change was slow to occur (Table 2). We discuss further how VPR methods highlight this gendered power imbalance in the sections below.

\section{Facilitating Meaningful Participation}

Meaningful participation of fringe stakeholders pertains to who is included, how they are included and whether their inputs can challenge decision-making through involvement in research (Mohan, 2001). In Ghana, some supplier staff were at first cautious, even cynical, about the GALS method on cocoa farms. They cited the high number of non-literate farmers as being the main reason for their concern, and didn't want to include the less-educated, poorer or migrant farmers in the sample in case they 'ruined' the research. After the first workshop, however, they saw how GALS cut across many levels of literacy, education, language and penmanship, and how this enabled participation regardless of age, gender, ethnic group or income level (Mayoux \& Chambers, 2005; Mayoux \& ANANDI, 2005). Supplier staff were enthusiastic about the interest and energy of participants compared to past research experience: 
[I liked] especially [that] the older people that were drawing. That was important. And that they understand what they were doing. For me, I don't think the nice drawing don't matter that much. (Follow-Up Interview with Supplier Staff 2).

Use of symbols for work tasks and items purchased created a 'universal language' (Mayoux, 2012, p.334), enabling participants of different backgrounds and local languages to participate (Liebenberg, 2009; Stiles, 2004). Conversations with local staff intimated that in other research approaches the older, less educated and very poor migrant farmers would not be included, since they would not be 'smart' enough (Supplier 2). The visual element of this particular participatory method helped to circumvent this usual bias, since the levelling and inclusive act of drawing provides a way of helping different fringe stakeholders to participate.

However, the visual element also highlighted how we were unable to be entirely inclusive of the supplier's most vulnerable fringe stakeholders, namely the unregistered wives of cocoa workers. We made a mistake in not clarifying that workshops were to be attended not only by cooperative members, but rather, by 'those that grow cocoa for the supplier'. It was not until we analysed the gender trees for membership versus work tasks that it became clear that a large number of female cocoa farmers was working on the land but these farmers were not members and therefore did not directly receive the benefits of fair trade: either in remuneration, training or other CSR initiatives. Restriction of cooperative membership to those that own the land, not necessarily those that work the land, continues to be a contentious point within the cooperative, and in fair trade more generally (Smith, 2013). GALS therefore enabled meaningful participation of those invited, but it also prompted us to reflect on stakeholder participation in the research design (Mosse, 2001) as well as in the business - and whether those who needed fair trade the most were able to access it. This is closely connected with the issue of voice. 


\section{Facilitating Voice}

That women farmers often receive no fair trade benefits was only revealed visually in GALS: it was not a subject that would necessarily be vocally raised within focus group or individual interviews, due in part to the 'naturalised' acceptance of gender inequality. Women 'helped' men on the farm, they were not farmers, they explained. Their drawings, however, showed that they were in fact working regularly as farmers, provoking vocal discussions on the part of both male and female farmers. Thus, the visual in VPR methods can facilitate the 'voice' of particular fringe stakeholders and their issues. Another example relates to women's 'triple shift' work (performing paid work, supplementary paid work and household/caring work) (Table 3). The gender trees provided a compelling and visually arresting representation of this, and we were able to use the drawings to collate statistics on work. The drawings provoked conversations about this unequal 'balance' as participants referred to their 'trees' to express personal opinions on their roles, even when that involved admitting that current behaviour was unfair. Men in a number of workshops announced that they were going to begin helping with childcare, and some women told how they were going to save collectively to tide over household budgets in the low cocoa season. In discussion, one women's group explained that the most useful aspect of GALS had been the bringing together of men and women to talk about sensitive topics, and to visually demonstrate to the men that women were working extremely hard.

That is not to say, however, that conflict over 'voice' did not arise. Male farmers in particular were initially confused as to why they needed to be included in the 'women's thing', but as the workshop continued the novelty of drawing helped include them. The resulting images 
were hard to ignore, even for those that were sceptical of the workshop. One male participant asked: 'You want us to believe that the women are suffering more than us?' but other male participants, indicating the drawings, answered, 'But it's true, that's a problem' (Focus Group Discussion 4). This is also indicative of the utility of VPR methods in groups - despite issues with possible 'bias' in such a setting (see Appendix 1 \& 2) ultimately a group setting facilitates voice since it is not the facilitator, an 'outsider', who provides support or counterpoints, but other participants.

VPR methods may also help generate visual and verbal data that might not otherwise be 'voiced', either due to cultural limitations (Jackson, 2012) or simply for a lack of words to convey suitable meaning (Warren, 2005). For example, in drawing the 'trees' many women refused to include the gender CSR income activities (e.g. batik and soap crafts) as work symbols. During the discussion, we were then able to ask why this was so, and it transpired that these were not seen as income-generating skills, especially in areas far from towns, where batik was seen as a luxury and imported soap preferred. Again, a combination of visual with verbal methods enabled us to 'hear' fringe stakeholders' actual evaluation of the CSR programme. The act of drawing enables space for reflection and presents an alternative format for stakeholder 'dialogue' to take place.

Finally, supplier staff became more aware of gendered divisions of labour and, crucially, enabling the voice of fringe stakeholders challenged their assumptions on collecting data:

They are smart. And I wasn't expecting them to be that smart. Looking at some of the answers that they give, to some of the questions, how they answer it -they know what 
they are about. You cannot, like, force things on them. In all, I learned that with a little help, the women can do marvelous things (Supplier 1).

Thus VPR methods can not only gather credible data for scholarly research but help challenge organisational assumptions about what fringe stakeholders can communicate.

\section{Readdressing Power Imbalances}

Power appears in two forms within our case study. First, as discussed in the first half of the article, there will always be a power imbalance between the researcher and participants, which has effects on the ethics and credibility of the research (Gaventa \& Cornwall, 2001). In order to address some of these problems in B\&S research, with a method such as GALS, researchers are better deployed as 'facilitators' who 'lead from the back', 'never touch the marker pen' and allow participants to contribute in their own surroundings (Mayoux, 2010, p.20). The act of drawing provoked reflection that resulted in the farmers providing new ideas and strategies for gender equality, that we as researchers could feed back to the organisation:

They are willing to change because nobody sat somewhere, and [said], 'You should do this, you shouldn't do that (Supplier staff 1).

Instead they came up with ideas on their own, and you see that they understand the concepts (Supplier staff 2).

Thus the process of engaging in VPR methods is useful not only for facilitating the voice and power of fringe stakeholders, but can be beneficial for associated stakeholders such as employees, NGO officers and researchers. VPR methods can help challenge our taken-for- 
granted assumptions about what power may be, and who may 'hold' it. As Jackson (2012) explains, mainstream research methods have privileged the verbal over all else, which means power is often conceived in a vocal form. In fact:

Women are already participating, but in neglected contexts; they have power as listeners in many participation roles, and as speakers in multiple registers and production formats through which they embed, unsettle and resignify language. The challenge for researchers, and development practitioners, is to improve their ability to listen and hear (Jackson, 2012, p.1000).

VPR methods, such as GALS, can help B\&S researchers to reflect on their own role, assumptions and prejudices (Cornwall, 1998) thereby enabling more credible data to emerge. Businesses too, when involved in research such as ours, can have an 'eye-opening' experience (Supplier Staff 3).

That societal power imbalances may be addressed through VPR methods is a more controversial claim (Crawley, 1998), and addressing gender inequality is particularly difficult (Riisgaard et al., 2010). The case study here cannot provide evidence that the workshops led to large-scale social change, although we saw in workshops how men and women used the visual form to first draw attention to, and then address some inequalities. For example, comparison of husbands' and wives' trees showed that men consistently under-estimated the amount of domestic work women had to carry out (see Figs.3 \& 4). When asked to circle the household task that took the longest to perform, men ignored domestic chores and focused on cocoa, whilst women pointed out their heavy domestic workload. That unpaid carework did not even figure on some of the men's drawings highlighted to participants, supplier staff and researchers the 
ingrained acceptance of women's servitude to the home. Cooking, especially, is a deep-seated, gendered cultural value in Ghana (Clark, 1995). The drawings prompted heated discussions around these assumptions, and about how much women were contributing to the household ('The roots are almost covering us!' (Focus group discussion 4)), yet receiving very little in terms of decision-making or freedom:

The women do double-work, mean that, after assisting with farm work, when they come home they also do the household chores, so it is hard work for the women. We see that when it comes to the roots of the tree, it is somewhat destroying the women (Male participant, focus group discussion 4).

Challenging power relations between men and women is a process that may be facilitated by outsiders, such as CSR programmes, or researchers, but ultimately is a grassroots issue that needs to be led by the people within communities (Rowlands, 1997). GALS can help start this process, because it concentrates on the individual's role in perpetuating inequalities whilst showing how they can also make changes to their circumstances (Mayoux, 2012). We do not claim that VPR methods alone will 'empower' women or other fringe stakeholders, and we are mindful of not pushing the onus for social change onto the least powerful. However, VPR workshops may begin a process of reflection and empowerment that could later bring about larger changes in societal dynamics (Crawley, 1998; Mayoux, 2012), as has been demonstrated in the use of GALS in Uganda (Mayoux, 2012). In our case, GALS has now been introduced into all the NGO partners' work with fair trade businesses, and the supplier has also initiated a new round of research using the method, in new regions, of which we shall take part (Email communication with NGO, December 2015). As a result of GALS findings, the supplier redesigned their gender policy and introduced changes to the gender programme: tailoring income 
generation better to women's actual market opportunities, and starting literacy classes to enable women to take on more roles in the cooperative, such as cocoa purchasing clerks (Telephone conversation with NGO, 2016).

The power differential between researcher and participant will always be present. Entrance and exit of research sites are particularly problematic. Care must be taken in terms of seeking informed consent (Liamputtong, 2007): considering the linguistic barriers in place with many fringe stakeholders (e.g. non-literacy and different languages with varying concepts), the sudden production of the standard university ethics consent form is often not appropriate. Instead, we explained in clear terms the reason for the research, the expectations of the day, anonymity of participants and, importantly, the right to withdraw from the workshop at any time. After workshops, it is difficult to promise a means of getting back in touch with participants, especially in rural areas or in places without access to the Internet. In our case, local partners were asked to get back in touch with us if participants requested it. Yet this is an imperfect situation due to potential conflicts between NGO (again, acting as a proxy) and fringe stakeholders.

VPR methods are not a magic bullet for collecting 'the truth' from fringe stakeholders, or worse, 'extracting' the 'thing we want to hear' (Mayoux \& ANANDI, 2005) but a novel means of generating data in challenging research contexts, and uncovering different ways of seeing difficult concepts. Our case study has demonstrated how the participatory and visual elements of GALS complemented the verbal, more traditional data collected in B\&S research such as ours. Specifically, paying attention to fringe stakeholders, such as women farmers, in terms of their inclusion and then involvement in the research, opened up more meaningful participation than if we had just asked questions of the group, given the ingrained inequality between men and 
women's right to speak to outsiders (Jackson, 2012). 'Voice' is enabled, paradoxically, though visual communication, and VPR methods opened up sensitive topics to researchers and suppliers. Finally, although we are careful not to overstate the outcomes of just one piece of research, VPR methods, as in our case, can challenge power relations between researcher and participant, by allowing participants to circumnavigate linguistic and cultural barriers through a more universal entry point: drawing. The method also has the potential to be used as a gender sensitisation exercise which sparks difficult conversations (e.g. on gender roles) in communities usually untouched by organisational scholarship.

\section{Discussion and Conclusion}

VPR methods are not without their limitations. Their operationalisation requires sensitivity, time and resources. Like any kind of fieldwork, patience and flexibility is key. VPR methods can be time-consuming and relatively expensive: they require travelling to fringe stakeholders themselves, often deep into rural areas as in our case, and sometimes into uncomfortable settings. As Gaventa \& Cornwall (2001) caution, participatory methodologies could easily be reduced to a tick-box exercise by researchers, companies, NGOs or aid agencies alike, eroding the three benefits to the approach as outlined in this article, and inviting the criticisms of superficiality or manipulation levied at many approaches to stakeholder engagement (e.g. Blowfield and Frynas, 2005; Owen et al., 2001).

In our GALS case study we followed a particularly structured process for facilitating participants' drawings and, later, analysing them. In following a set of guidelines, suggesting symbols, and using a framework such as the 'Gender Tree' we may have restricted issues that 
were pertinent to our research, or pressured participants into drawing certain things. Whilst we took great efforts to reassure participants that they should not feel they had to draw anything irrelevant to them or copy each other, this remains a valid concern. On the other hand, a structured process, in a group setting, worked for our particular context (largely non-literate, low educational attainment communities) and our research questions. Using the tree as a metaphor, and symbols that are tightly connected to economic and labour roles produced data related to those aspects of participants' lives. Other researchers may like to experiment with more freehand VPR methods which give participants more freedom. Of course, this opens up another limitation of VPR methods: analysis (see also Appendix 2). The analysis of images will always be open to a certain amount of subjective interpretation, as is the way with art (Berger, 1972) as well as text (Barthes, 1967). Thus the combination of visual with verbal, in the form of a triangulation of methods, is useful. Incorporating VPR methods with interviews, observation and secondary literature adds to the credibility and transferability of the approach (Jackson, 2012) and better captures the multi-sensory realities of social practices (Küpers, 2014).

VPR methods are not a panacea for B\&S research methodology, but they do offer new avenues for how B\&S research is carried out, with fringe stakeholders central to the research design. Faced with multiple, growing global problems, a 'bottom-up approach' to B\&S research is arguably required to achieve the 'full emancipatory potential of CSR' (Idemudia, 2011, p.13). How might we, as B\&S researchers, help 'make corporate social responsibility work for society and not just for corporations' (Banerjee, 2008, p.73)? We argue that one step in the right direction is to attend meaningfully to the concept of fringe stakeholders, by reconsidering their participation, voice and power in research designs, which leads to credible research and recommendations. We suggest that $B \& S$ researchers embrace VPR methods that place fringe 
stakeholders at the centre of the enquiry (as opposed to the business). Complementing the verbal with the visual allows for different 'ways in' to studying social practices, such as gender, which are so often taken-for-granted (Martin, 2003). VPR methods could then help us better understand on-the-ground experiences, gather credible evaluations and validate decision-making (Wicks, Gilbert Jr, \& Freeman, 1994).

We thus contribute to $\mathrm{B} \& \mathrm{~S}$ methodologies through applying and developing VPR methods to complement traditional, verbal methods. First, VPR methods enable more meaningful participation of fringe stakeholders. We argue that meaningful participation goes beyond simply including a new category of person within research, but rather necessitates getting closer to individuals' feelings and opinions about sensitive topics. As we demonstrate, drawing, in particular, is a means of communication that enables reflection in participants' 'answers' that instant verbal responses may not (Gauntlett \& Holzwarth, 2006) and offers alternative avenues into difficult concepts and feelings. Relatedly, we build upon the concept of 'voice' in B\&S research (Le Ber \& Branzei, 2010) by demonstrating how 'voice' is not only captured through the verbal, but through visual methods which allow for deeper reflection on gender practices, roles and opinions about these. The context of our study also serves to contribute to the notion of voice in visual organisation studies (Warren, 2005) through complicating assumptions about who has 'voice' and how in some cultural contexts moving beyond the vocal may be more enabling than forcing speech (see also Jackson, 2012). We also contribute to B\&S research methodologies through demonstrating how VPR methods can challenge some of the power relations inherent in research practice, and critically discuss how VPR methods may contribute to a breaking down of more ingrained power imbalances, such as those between genders in value chains. These factors taken together, we argue, mean that the use of VPR methods in B\&S research can promote more 
credible research which aims to include fringe stakeholders, who have otherwise become more visible, yet no more easily accessed within CSR (Hart \& Sharma, 2004).

We also contribute to the field of visual organisation studies through this new application. 'Wicked problems', such as gender inequality (in this case), climate change, HIV/AIDS, international terrorism, abject poverty and a whole range of issues traverse institutions, organisations and groups of people, and go beyond one governance form (Scherer \& Palazzo, 2011). Accordingly, we argue that adopting VPR methods to study these topics not only attends to issues of voice, participation and power in research design, but shows promise for developing VPR methods for organisation studies, in terms of context, actors and topic. B\&S research necessitates a broader understanding of the context of organisations: beyond legal definitions, traditional notions of responsibility, and across physical boundaries and definitions of stakeholders, including those outside of employment or contractual relationships (Rasche et al., 2013; Scherer \& Palazzo, 2011). B\&S topics, we have argued, attend to 'wicked problems' that, whilst global in reach, are often present in taken-for-granted, dynamic, temporal, everyday practice, (Thatchenkery, Avital \& Cooperrider, 2010). VPR methods can help capture practice along these lines (Höllerer et al., 2013). Therefore, we argue that B\&S researchers could experiment with VPR methods in contexts with which they are familiar, whilst at the same time urging experienced visual theorists to turn their attention to the less-visited sites and groups of people where global tensions are at their most taut.

With this in mind, we finish with some suggested avenues for future research utilising VPR methods such as GALS. For example, using drawing with individuals to capture their understanding of climate change and their personal responsibility as consumers could not only gather their opinions, but open up conversations about recycling and reduction of energy use. 
Building on the use of drawing to delve into identities (e.g. Meyer, 1991), B\&S researchers exploring sustainability could employ VPR methods to explore assumptions of supplier and MNC responsibility in global trade, perhaps experimenting with the method in individual or group settings. Research into other fringe stakeholders, such as indigenous peoples, modern day slaves or child labourers could benefit from the use of VPR methods: photographs to capture documentary experiences, or free-hand sketching to metaphorically explore their livedexperience. Within offices, researchers could explore complex topics, such as global financial trading, or internet privacy standards, through VPR methods that use drawing to unpack individuals' sense of ethics. The options for using VPR methods, especially drawing, in research at the intersection of business and society are vast, and as we have argued in this article, offer complementary inroads to more inclusive research, credible findings and impact.

\section{Acknowledgements}

The authors wish to thank Jeremy Moon, Michael Humphreys and Roy Suddaby for advice on earlier versions of this article. They also wish to thank Andrew Crane as the special issue coeditor handling the article, and three anonymous reviewers for their helpful comments.

\section{Funding Acknowledgement}

This research received no specific grant from any funding agency in the public, commercial, or not-for-profit sectors. 


\section{Declaration of Conflicting Interests}

The authors declared that they had no conflicts of interest with respect to their authorship or the publication of this article.

\section{Notes on contributors}

Lauren McCarthy ( $\mathrm{PhD}$, The University of Nottingham) is an Assistant Professor of Sustainability and Governance in the Centre for Corporate Social Responsibility, Copenhagen Business School. Her research interests centre on gender and CSR, value chains, feminism, and the use of participatory visual methodologies in research and CSR practice. She contributes to The Guardian and regularly tweets @genderCSR.

Judy N. Muthuri (PhD, The University of Nottingham) is an Associate Professor of Corporate Social Responsibility at the International Centre for Corporate Social Responsibility (ICCSR), Nottingham University Business School. Her research interests are in the areas of corporate social investment, partnerships, sustainable supply chain management, corporations and development, and CSR in Africa. Her published work appears in the British Journal of Management, Community Development Journal, Journal of Business Ethics, and Journal of Corporate Citizenship. She is a founding executive committee member of the Africa Academy of Management. 


\section{References}

Aguinis, H., \& Glavas, A. (2012). What we know and don't know about corporate social responsibility: A review and research agenda. Journal of Management, 38(4), 932-968.

Arnstein, A. (1969). A ladder of citizenship participation. Journal of the American Institute of Planners, 25(3), 216-233.

Auret, D., \& Barrientos, S. (2004). Participatory social auditing: A practical guide to developing a gender sensitive approach. Sussex: Institute for Development Studies.

Banerjee, S. B. (2008). Corporate social responsibility: The good, the bad and the ugly. Critical Sociology, 34(1), 51-79.

Banerjee, S. B. (2011). Voices of the governed: towards a theory of the translocal. Organization, $18(3), 323-344$.

Bansal, P., \& Corley, K. G. (2011). The coming of age for qualitative research: Embracing the diversity of qualitative methods. Academy of Management Journal, 54(2), 233.

Barrientos, S. (2014). Gendered global production networks: Analysis of cocoa-chocolate sourcing. Regional Studies, 48(5), 791-803.

Barthes, R. (1967). Death of the author. In Barthes, R. (1967). Image, Music, Text (pp.142-148). Illinois: Fontana Press.

Barthes, R. (1993). Camera Lucida. London: Vintage Press.

Baudrillard, J. (1983) Simulations. Trans. P. Foss, P. Patton \& P. Beitchman. New York: Semiotext(e).

Bell, P. (2001). Content analysis of visual images. In T. van Leuwen \& C. Jewitt (Eds.), Handbook of Visual Analysis (pp.10-34). London, Thousand Oaks, New Delhi: Sage.

Bell, E., \& Davison, J. (2013). Visual management studies: empirical and theoretical approaches. International Journal of Management Reviews,15(2), 167-184. 
Benschop, Y., \& Meihuizen, H. E. (2002). Keeping up gendered appearances: representations of gender in financial annual reports. Accounting, Organizations and Society, 27(7), 611-636.

Berger, P. (1972). Ways of Seeing. London and New York: Penguin.

Berger, P. L., \& Luckmann, T. (1967). The social construction of reality: A systematic treatise in the sociology of knowledge. New York: Anchor.

Blowfield, M. E., \& Dolan, C. S. (2008). Stewards of virtue? The ethical dilemma of CSR in African agriculture. Development and Change, 39(1), 1-23.

Blowfield, M. E., \& Frynas, J. G. (2005). Setting new agendas: Critical perspectives on Corporate Social Responsibility in the developing world. International Affairs, 81(3), 499-513.

Borgerson , J. L., \& Schroeder, J.E. (2002). Ethical issues of global marketing: avoiding bad faith in visual representation. European Journal of Marketing, 36(5/6), 570-594.

Broussine, M. \& Vince, R. (1996). Working with metaphor towards organizational change. In Oswick, C. \& Grant, D. (Eds.), Organizational Development: Metaphorical Analysis (pp.57-72). London: Pitman.

Bryans, P., \& Mavin, S. (2006). Visual images: A technique to surface conceptions of research and researchers. Qualitative Research in Organizations and Management, 1(2), 113-128.

Burchell, J., \& Cook, J. (2006). It's good to talk? Examining attitudes towards corporate social responsibility dialogue and engagement processes. Business Ethics: A European Review, 15(2), 154-170.

Burns, D., Hyde, P., Killett, A., Poland, F., \& Gray, R. (2014). Participatory organizational research: Examining voice in the co-production of knowledge. British Journal of Management, 25(1), 133-144.

Butler, F. (2014). Valuing unpaid labour in community Fair Trade products: a Nicaraguan case study from The Body Shop International. Gender \& Development, 22(3), 533-547

Capelle, J. (2009). Towards a sustainable cocoa chain: Power and possibilities within the cocoa and chocolate sector. Montreal, Canada: Oxfam. 
Castleden, H., Garvin, T., \& First Nation (2008). Modifying Photovoice for community-based participatory Indigenous research. Social Science and Medicine, 66(6), 1393-1405.

Chambers, R. (1997). Whose reality counts? Putting the first last. London: Intermediate Technology Publications.

Clark, G. (1995). Onions are my husband: Survival and accumulation by West African market women. Chicago: University of Chicago Press.

Cornwall, A. (1998). Gender, participation and the politics of difference. In I. Gujit \& M. K. Shah (Eds.), The myth of community: Gender issues in participatory development (pp.16-27). Rugby, United Kingdom: ITDG Publishing.

Cornwall, A. (2014). Women's empowerment. What works and why? (WIDER Working paper 2014/104). Helsinki: World Institute for Development Economics Research.

Crane, A. (2013). Modern slavery as a management practice: Exploring the conditions and capabilities for human exploitation. Academy of Management Review, 38(1), 49-69.

Crawley, H. (1998). Living up to the empowerment claim? The potential of PRA. In I. Gujit \& M. K. Shah (Eds.), The myth of community: Gender issues in participatory development (pp.2434). Rugby, United Kingdom: ITDG Publishing.

Davison, J., McLean, C., \& Warren, S. (2012). Exploring the visual in organizations and management. Qualitative Research in Organizations and Management: An International Journal, 7(1), 5-15.

De Bakker, F. G. A., \& Den Hond, F. (2008). Introducing the politics of stakeholder influence: A review essay. Business \& Society, 47(1), 8-20.

De Bakker, F. G. A., Groenewegen, P., \& Den Hond, F. (2006). A research note on the use of bibliometrics to review the corporate social responsibility and corporate social performance literature. Business \& Society, 45(1), 7-19.

Dolan, C., Johnstone-Louis, M., \& Scott, L. (2012). Shampoo, saris and SIM cards: seeking entrepreneurial futures at the bottom of the pyramid. Gender \& Development, 20(1), 33-47. 
Donaldson, T., \& Preston, L. E. (1995). The stakeholder theory of the corporation: Concepts, evidence, and implications. Academy of Management Review, 20(1), 65-91.

Farnworth, C. (2011). Gender-aware value chain development. (Expert paper prepared for UN Women). London: UN Women.

Foucault, M. (1973). The order of things. Trans. Alan Sheridan. New York: Vintage.

Freeman, R. E. (1984). Strategic management: A stakeholder approach (2010 ed.). Cambridge, United Kingdom: Cambridge University Press.

Freire, P. (1970). Cultural action and conscientization. Harvard Educational Review, 40(3), 452477.

Frynas, J. G. (2005). The false developmental promise of corporate social responsibility: evidence from multinational oil companies. International Affairs, 81(3), 581-598.

Gauntlett, D. (1996). Video critical: children, the environment and media power. New Barnet, United Kingdom: John Libbey Media.

Gauntlett, D., \& Holzwarth, P. (2006). Creative and visual methods for exploring identities. Visual Studies, 21(1), 82-91.

Gaventa, J., \& Cornwall, A. (2001). Power and knowledge. In P. Reason \& H. Bradbury (Eds.), Handbook of action research, participative inquiry \& practice (pp.70-80). London: Sage.

Giddens, A. (1984). The constitution of society: Outline of the theory of structuration. Berkeley: University of California Press.

Gioia, D. A., Corley, K. G., \& Hamilton, A. L. (2013). Seeking qualitative rigor in inductive research notes on the Gioia methodology. Organizational Research Methods, 16(1), 15-31.

Goffman, E. (1979). Gender Advertisements. London: Allen Lane.

Golob, U., \& Podnar, K. (2014). Critical points of CSR-related stakeholder dialogue in practice. Business Ethics: A European Review, 23(3), 248-257. 
Gombrich, E. (1982). The image and the eye: Further studies in the psychology of pictorial representation. Oxford, United Kingdom: Phaidon.

Greenwood, M. (2007). Stakeholder engagement: Beyond the myth of corporate responsibility. Journal of Business Ethics, 74(4), 315-327.

Grosser, K. (2009). Corporate social responsibility and gender equality: women as stakeholders and the European Union sustainability strategy. Business Ethics: A European Review, 18(3), 290-307.

Gujit, I., \& Kaul Shah, M. (1998). Waking up to power, conflict and process. In I. Gujit \& M. Kaul Shah (Eds.), The myth of community: Gender issues in participatory development (pp.120). Rugby, United Kingdom: ITDG Publishing.

Guthey, E., \& Jackson, B. (2005). CEO portraits and the authenticity paradox. Journal of Management Studies, 42(5), 1057-1082

Hart, S. L., \& Sharma, S. (2004). Engaging fringe stakeholders for competitive imagination. Academy of Management Executive, 18(1), 7-18.

Hirschmann, A. (1970). Exit, voice and loyalty: Responses to the decline in firms, organisations and states. Cambridge, Mass: Harvard University Press.

Höllerer, M. A., Jancsary, D., Meyer, R. E., \& Vettori, O. (2013). Imageries of corporate social responsibility: visual recontextualisation and field-level meaning. Research in the Sociology of Organizations: Communities and Organizations, 39(B), 139-174.

Idemudia, U. (2011). Corporate social responsibility and developing countries: moving the critical CSR research agenda in Africa forward. Progress in Development Studies, 11(1), 1-18.

Jackson, C. (2012). Speech, gender and power: Beyond testimony. Development and Change, 43(5), 999-1023.

Jamali, D., \& Sidani, Y. (2011). Is CSR counterproductive in developing countries? The unheard voices of change. Journal of Change Management, 11(1), 69-71. 
Jordan, L., \& van Tuiji, P. (2006). NGO Accountability: Politics, Principles and Innovations. London: Earthscan.

Karnani, A. G. (2007). Doing well by doing good-case study: 'Fair \& Lovely' whitening cream. Strategic Management Journal, 28(13), 1351-1357

Kearney, K. S., \& Hyle, A. E. (2004). Drawing out emotions: the use of participant-produced drawings in qualitative inquiry. Qualitative Research, 4(3), 361-382.

Khan, F. R., \& Lund-Thomsen, P. (2011). CSR As imperialism: Towards a phenomenological approach to CSR in the developing world. Journal of Change Management, 11(1), 73-90.

Khan, F. R., Munir, K. A., \& Willmott, H. (2007). A dark side of institutional entrepreneurship: Soccer balls, child labour and postcolonial impoverishment. Organization Studies, 28(7), 10551077.

Küpers, W. (2014). Between the visible and the invisible in organizations. In Bell, E., Warren, S. \& Schroder, J.E. (Eds.) (2014) The Routledge Companion to Visual Organization (pp.19-32). London \& New York: Routledge.

Ladkin, D. (2004). Action research. In C. Searle, G. Gobo, J. F. Gubrium, \& D. Silverman (Eds.), Qualitative Research Practice (pp.536-548). London, Thousand Oaks, New Delhi: Sage.

Lang, S. (2012). NGOs, civil society, and the public sphere. Cambridge, United Kingdom: Cambridge University Press.

Le Ber, M. J., \& Branzei, O. (2010). Towards a critical theory of value creation in cross-sector partnerships. Organization, 17(5), 599-629.

Levin, K., Cashore, B., Bernstein, S., \& Auld, G. (2012). Overcoming the tragedy of super wicked problems: constraining our future selves to ameliorate global climate change. Policy Sciences, 45(2), 123-152.

Liamputtong, P. (2007). Researching the vulnerable. London, Thousand Oaks, New Delhi: Sage. 
Liebenberg, L. (2009). The visual image as discussion point: increasing validity in boundary crossing research. Qualitative Research, 9(4), 441-467.

Lockett, A., Moon, J., \& Visser, W. (2006). Corporate social responsibility in management research: Focus, nature, salience and sources of influence. Journal of Management Studies, 43(1), 115-136.

Martin, P. Y. (2003). "Said and done" versus "saying and doing" gendering practices, practicing gender at work. Gender \& Society, 17(3), 342-366

Matilal, S., \& Höpfl, H. (2009). Accounting for the Bhopal disaster: footnotes and photographs. Accounting, Auditing \& Accountability Journal, 22(6), 953-972.

Mayes, R., Pini, B., \& McDonald, P. (2012). Corporate social responsibility and the parameters of dialogue with vulnerable others. Organization, 20(6), 840-859.

Mayoux, L. (2010). Tree of diamond dreams: Visioning and committing to action on gender justice. Manual for Field-Testing and Local Adaptation. GALS stage 1. Den Haag. Available at: http://www.wemanglobal.org/documents/Vision/Tree of diamond dreams.pdf.

Mayoux, L. (2012). Gender mainstreaming in value chain development: Experience with Gender Action Learning System in Uganda. Enterprise Development and Microfinance, 23(4), 319-337.

Mayoux, L., \& ANANDI. (2005). Participatory action learning system (PALS): Impact assessment for civil society development and grassroots-based advocacy in Anandi, India. Journal of International Development, 17(1), 211-242.

Mayoux, L., \& Chambers, R. (2005). Reversing the paradigm: quantification, participatory methods and pro-poor impact assessment. Journal of International Development, 17(1), 271298.

Mayoux, L., \& Mackie, G. (2007). Making the strongest links. Geneva, Switzerland: ILO.

Meyer, A. D. (1991). Visual data in organizational research. Organization Science, 2(May), 218237. 
Meyer, R. E., Höllerer, M. a, Jancsary, D., \& van Leeuwen, T. (2013). The visual dimension in organizing, organization, and organization Research: Core ideas, current developments, and promising avenues. Academy of Management Annals, 7(1), 489-555.

Mitchell, R. K., Agle, B. R., \& Wood, D. T. (1997). Toward a theory of stakeholder identification and salience: Defining the principle of who and what really counts. Academy of Management Review, 22(4), 853-886.

Mitchell, W.J.T. (1994). Picture theory. Chicago: University of Chicago Press.

Mohan, G. (2001). Participatory development. In V. Desai \& R. Potter (Eds.), The Arnold companion to development studies (pp.49-54). London: Hodder.

Morgan, D. L. (1997). Focus groups as qualitative research. (2nd ed.). Thousand Oaks: Sage.

Morsing, M., \& Schultz, M. (2006). Corporate Social Responsibility communication: Stakeholder information, response and involvement strategies. Business Ethics: A European Review, 15(4), 323-338.

Mosse, D. (2001). People's knowledge, participation and patronage: Operations and representations in rural development. In B. Cooke \& U. Kothari (Eds.), Participation: The New Tyranny? (pp.16-35). London and New York: Zed Books.

Murphy, M., \& Arenas, D. (2010). Through indigenous lenses: Cross-sector collaborations with fringe-stakeholders. Journal of Business Ethics, 94(1), 103-121.

Muthuri, J. N. (2007). Participation and accountability in corporate community involvement programmes: a research agenda. Community Development Journal, 43(2), 177-193.

Narayanasamy, N. (2009). Participatory rural appraisal: Principles, methods and application. New Delhi, India: Sage Publications.

O’Rourke, D. (2002). Monitoring the monitor: A critique of Price Waterhouse Coopers (PwC) labor monitoring. Available at: www.web.mit.edu/dorourke/www.index.html. 
O'Neill, M. (2008). Transnational refugees: The transformative role of art? Forum Qualitative Sozialforschung /Forum: Qualitative Social Research,9(2). Available at: http://nbnresolving.de/urn:nbn:de:0114-fqs0802590.

Owen, D. L., Swift, T., \& Hunt, K. (2001). Questioning the role of stakeholder engagement in social and ethical accounting, auditing and reporting. Accounting Forum, 25(3), 264-282.

Parent, M. M., \& Deephouse, D. L. (2007). A case study of stakeholder identification and prioritization by managers. Journal of Business Ethics, 75(1), 1-23.

Pedersen, E. R. (2006). Making Corporate Social Responsibility (CSR) operable: How companies translate stakeholder dialogue into practice. Business and Society Review, 111(2), $137-163$.

PhotoVoice (2014) MyPharm - A story of change with farmers in rural Ghana. Available at: https://photovoice.org/mypharm.

Pink, S. (2001). Visual ethnography: Images, media and representation in research. London: Sage.

Prahalad, C. K., \& Hammond, A. (2002). Serving the world's poor, profitably. Harvard business review, 80(9), 48-59.

Prieto-Carrón, M., Lund-Thomsen, P., Chan, A., Muro, A., \& Bhushan, C. (2006). Critical perspectives on CSR and development: what we know, what we don't know, and what we need to know. International Affairs, 82(5), 977-987.

Rämö, H. (2011). Visualizing the phronetic organization: The case of photographs in CSR reports. Journal of Business Ethics, 104(3), 371-387

Rasche, A., \& Chia, R. (2009). Researching strategy practices: A genealogical social theory perspective. Organization Studies, 30(7), 713-734.

Rasche, A., \& Esser, D. E. (2006). From stakeholder management to stakeholder accountability. Journal of Business Ethics, 65(3), 251-267. 
Rasche, A., Bakker, F.G.A., \& Moon, J. (2013). Complete and partial organizing for corporate social responsibility. Journal of Business Ethics, 115(4), 651-663.

Reason, P. (1994). Participation in human inquiry. London: Sage.

Reed, M. S. (2008). Stakeholder participation for environmental management: a literature review. Biological conservation, 141(10), 2417-2431.

Riisgaard, L., Escobar Fibla, A. M., \& Ponte, S. (2010). Gender and value chain development. Copenhagen, Denmark: DANIDA.

Rose, G. (2003). On the need to ask how, exactly, is geography "visual”?. Antipode, 35(2), 212221.

Rowlands, J. (1997). Questioning empowerment: Working with women in Honduras. Oxford, United Kingdom: Oxfam.

Scherer, A. G., \& Palazzo, G. (2011). The new political role of business in a globalized world: A review of a new perspective on CSR and its implications for the firm, governance, and democracy. Journal of Management Studies, 48(4), 899-931.

Shortt, H. \& Warren, S. (2012). Fringe benefits: Valuing the visual in narratives of hairdressers' identities at work. Visual Studies, 27(1), 18-34.

Smith, S. (2013). Assessing the gender impacts of Fairtrade. Social Enterprise Journal, 9(1), $102-122$.

Spencer, S. (2011). Visual research methods in the social sciences. London: Routledge.

Stiles, D. R. (2004). Pictorial representation. In C. Cassell \& G. Symon (Eds.), Essential guide to qualitative methods in organizational research (pp.127-139). London: Sage.

Stiles, D. R. (2011). Disorganization, disidentification and ideological fragmentation: Verbal and pictorial evidence from a British business school. Culture and Organization, 17(1), 5-30. 
Stiles, D. R. (2013). Drawing as a method of organizational analysis. In Bell, E., Warren, S. \& Schroeder, J.E. (Eds.), The Routledge Companion to Visual Organization (pp.247-242). London: Routledge.

Taneja, S. S., Taneja, P. K., \& Gupta, R. K. (2011). Researches in Corporate Social Responsibility: A review of shifting focus, paradigms, and methodologies. Journal of Business Ethics, 101(3), 343-364.

Thatchenkery, T. J., Cooperrider, D. L., \& Avital, M. (Eds.) (2010). Positive design and appreciative construction: from sustainable development to sustainable value. Bingley, United Kingdom: Emerald.

Thekkudan, J. \& Thandon, R. (2009). Women's livelihoods, global markets and citizenship. (IDS Working Paper 336). Sussex: Institute of Development Studies.

Tornhill, S. Forthcoming 2016. The wins of corporate gender equality politics: Coca-Cola and female microentrepreneurship in South Africa. In K. Grosser, L. McCarthy, \& M. A. Kilgour (Eds.), Gender and responsible business: Expanding CSR horizons. Sheffield: Greenleaf.

Touboulic, A. \& Walker, H.L. (2016). A relational, transformative and engaged approach to sustainable supply chain management: the potential of action research. Human Relations, 69(2), 301-343.

TWIN. (2013). Empowering women farmers in agricultural supply chains. London: TWIN.

UNECA. (2011). The African gender and development index 2011. Addis Ababa, Ethiopia: UNECA.

Utting, P. (2007). CSR and equality. Third World Quarterly, 28(4), 697-712.

Vince, R., \& Broussine, M. (1996). Paradox, defense and attachment: Accessing and working with emotions and relation underlying organizational change. Organization Studies, 17(1), 1-21. 
Vince, R., \& Warren, S. (2012). Participatory visual methods. In C. Cassell \& G. Symon (Eds.), The Practice of Qualitative Organizational Research: Core Methods and Current Challenges (pp.275-294). London: Sage.

Wang, C. C. (1999). Photovoice: A participatory action research strategy applied to women's health. Journal of Women's Health, 8(2), 185- 192.

Warren, S. (2005). Photography and voice in critical qualitative management research. Accounting, Auditing \& Accountability Journal, 18(6), 861-882.

West, C., \& Zimmerman, D. H. (1987). Doing gender. Gender \& society, 1(2), 125-151.

Wicks, A. C., Gilbert, D. R. Jr., \& Freeman, R. E. (1994). A feminist reinterpretation of the stakeholder concept. Business Ethics Quarterly, 4(4), 475-497.

World Bank (2011). World development report 2012: Gender equality and development. Washington: The World Bank.

Zuboff, S. (1998). In the age of the smart machine: The future of work and power. New York: Basic Books. 


\begin{tabular}{|c|c|c|c|c|}
\hline Workshop & Location & Participants & Forms of Data Collected & Totals \\
\hline 1 & $\begin{array}{l}\text { Ashanti Region, } \\
\text { Ghana }\end{array}$ & $\begin{array}{l}6 \text { men } \\
7 \text { women }\end{array}$ & $\begin{array}{l}\text { Household Drawings } \\
\text { Gender Tree Diagrams } \\
\text { Focus Group } \\
\text { Discussions } \\
\text { Observations } \\
\end{array}$ & $\begin{array}{l}13 \text { drawings } \\
13 \text { diagrams } \\
1 \text { hour } \\
3.5 \text { hours }\end{array}$ \\
\hline 2 & $\begin{array}{l}\text { Ashanti Region, } \\
\text { Ghana }\end{array}$ & $\begin{array}{l}4 \text { men } \\
6 \text { women }\end{array}$ & $\begin{array}{l}\text { Household Drawings } \\
\text { Gender Tree Diagrams } \\
\text { Focus Group } \\
\text { Discussions } \\
\text { Observations }\end{array}$ & $\begin{array}{l}10 \text { drawings } \\
10 \text { diagrams } \\
1 \text { hour } \\
3.5 \text { hours }\end{array}$ \\
\hline 3 & $\begin{array}{l}\text { Western Region, } \\
\text { Ghana }\end{array}$ & $\begin{array}{l}6 \text { men } \\
6 \text { women }\end{array}$ & $\begin{array}{l}\text { Household Drawings } \\
\text { Gender Tree Diagrams } \\
\text { Focus Group } \\
\text { Discussions } \\
\text { Observations } \\
\end{array}$ & $\begin{array}{l}12 \text { drawings } \\
12 \text { diagrams } \\
1 \text { hour } \\
3.5 \text { hours }\end{array}$ \\
\hline 4 & $\begin{array}{l}\text { Western Region, } \\
\text { Ghana }\end{array}$ & $\begin{array}{l}6 \text { men } \\
7 \text { women }\end{array}$ & $\begin{array}{l}\text { Household Drawings } \\
\text { Gender Tree Diagrams } \\
\text { Focus Group } \\
\text { Discussions } \\
\text { Observations } \\
\end{array}$ & $\begin{array}{l}13 \text { drawings } \\
13 \text { diagrams } \\
1 \text { hour } \\
3.5 \text { hours }\end{array}$ \\
\hline & & & Totals: & $\begin{array}{l}48 \text { drawings } \\
48 \text { diagrams } \\
4 \text { hours discussion } \\
14 \text { hours } \\
\text { observations }\end{array}$ \\
\hline
\end{tabular}

Table 1: Breakdown of GALS Workshops 


\begin{tabular}{|c|c|c|c|c|}
\hline $\begin{array}{ll}\text { Source } & \text { of } \\
\text { Raw Data } & \end{array}$ & First Order Concepts & Second Order Themes & $\begin{array}{l}\text { Aggregate } \\
\text { Dimensions }\end{array}$ & $\begin{array}{l}\text { Supporting } \\
\text { Literature }\end{array}$ \\
\hline $\begin{array}{l}\text { GALS } \\
\text { Household } \\
\text { drawing } \\
\text { (visual) }\end{array}$ & Average of 5 children per household & $\begin{array}{ll} & \begin{array}{l}\text { Gendered unpaid care } \\
\text { roles }\end{array} \\
\circ & \begin{array}{l}\text { Women have no time } \\
\text { for CSR initiatives }\end{array}\end{array}$ & \multirow{4}{*}{$\begin{array}{l}\text { Women's } \\
\text { subject positions } \\
\text { socially } \\
\text { constructed as } \\
\text { 'natural' }\end{array}$} & \multirow{4}{*}{$\begin{array}{l}\text { Barrientos } \\
(2014) ; \\
\text { Clark } \\
(1995) ; \\
\text { Cornwall } \\
(2016)\end{array}$} \\
\hline $\begin{array}{l}\text { GALS Gender } \\
\text { tree drawing } \\
\text { (visual) }\end{array}$ & $\begin{array}{l}\text { - Childcare on left hand side (women's work) } \\
\text { - Women circle domestic chores e.g. cooking as taking up the } \\
\text { most time in the day } \\
\text { - Men do not include domestic chores on their 'side' of the } \\
\text { tree, if at all } \\
\text { - Women omit drawing symbols for CSR initiative projects } \\
\text { e.g. batik } \\
\text { Clearing land and spraying are never drawn as women's } \\
\text { work. }\end{array}$ & \multirow{3}{*}{$\begin{array}{l}\text { Women's main roles } \\
\text { are as housekeepers } \\
\text { Women work the triple- } \\
\text { shift } \\
\text { Men are the } \\
\text { breadwinners } \\
\text { Women 'help' men on } \\
\text { the farm; cocoa is a } \\
\text { male crop } \\
\text { Resource scarcity/ } \\
\text { difficulty }\end{array}$} & & \\
\hline $\begin{array}{l}\text { GALS Group } \\
\text { discussions } \\
\text { (verbal) }\end{array}$ & $\begin{array}{l}\text { - Women explained that they don't make money from CSR } \\
\text { projects e.g. batik, so do not draw them. } \\
\text { 'The roots of the tree are almost destroying us' (Women's } \\
\text { group discussion) } \\
\text { 'The women are also burdened with the household chores... } \\
\text { they do double-work' (Men's discussion in plenary). } \\
\text { - Women cannot do clearing and spraying because they are } \\
\text { 'too dangerous' and because 'women have babies'. } \\
\text { Men claimed that they 'could hold the babies whilst the } \\
\text { women cook the evening meal' (Men's group discussion). }\end{array}$ & & & \\
\hline $\begin{array}{l}\text { GALS } \\
\text { Observations } \\
\text { (textual) }\end{array}$ & $\begin{array}{l}\text { 'Shrieks of laughter as I drew on my facilitator tree that my } \\
\text { male partner was cleaning and cooking. Cooking, in particular, } \\
\text { is such a female activity that even staff were amazed.' }\end{array}$ & & & \\
\hline
\end{tabular}

Table 2: Example of process of data analysis 


\begin{tabular}{|c|c|c|c|}
\hline & Women & Men & Shared \\
\hline $\begin{array}{l}\text { Cocoa } \\
\text { Work }\end{array}$ & $\begin{array}{l}\text { Fetching water, } \\
\text { weeding, planting, } \\
\text { breaking pods, } \\
\text { fermenting, drying. }\end{array}$ & $\begin{array}{l}\text { Spraying } \\
\text { pesticides/fertilisers, clearing } \\
\text { land, selling cocoa, } \\
\text { fermenting, breaking pods, } \\
\text { drying. }\end{array}$ & $\begin{array}{l}\text { Planting, Weeding, } \\
\text { Breaking pods, drying, } \\
\text { harvesting. }\end{array}$ \\
\hline $\begin{array}{l}\text { Other } \\
\text { Work }\end{array}$ & $\begin{array}{l}\text { Garden vegetable growing } \\
\text { and selling (e.g. cassava, } \\
\text { plantain and peppers); } \\
\text { Petty trading; Livestock } \\
\text { and fowl rearing; palm oil } \\
\text { extraction; batik-making. }\end{array}$ & $\begin{array}{l}\text { Rearing livestock; taxi- } \\
\text { services; petty trading. }\end{array}$ & N/A. \\
\hline $\begin{array}{l}\text { Domestic } \\
\text { Work }\end{array}$ & $\begin{array}{l}\text { Cooking food, fetching } \\
\text { water, childcare, fetching } \\
\text { firewood, laundry, } \\
\text { sweeping, }\end{array}$ & N/A & $\begin{array}{l}\text { Childcare, fetching } \\
\text { water. }\end{array}$ \\
\hline
\end{tabular}

Table 3: Women's, Men's and Shared Work ordered by most prevalent tasks. Tasks taking up the most time per day in bold. 


\begin{tabular}{|l|l|l|l|}
\hline & Male-owned & Female-Owned & Shared between both partners \\
\hline Land & $49 \%$ & $16 \% *$ & $35 \%$ \\
\hline Housing & $57 \%$ & $7 \%$ & $36 \%$ \\
\hline Money & $69 \%$ & $12 \%$ & $19 \%$ \\
\hline
\end{tabular}

${ }^{*}$ Half of these were widowers who inherited land

Table 4: Ownership of Assets by Sex (percentage of GALS workshops participants) 


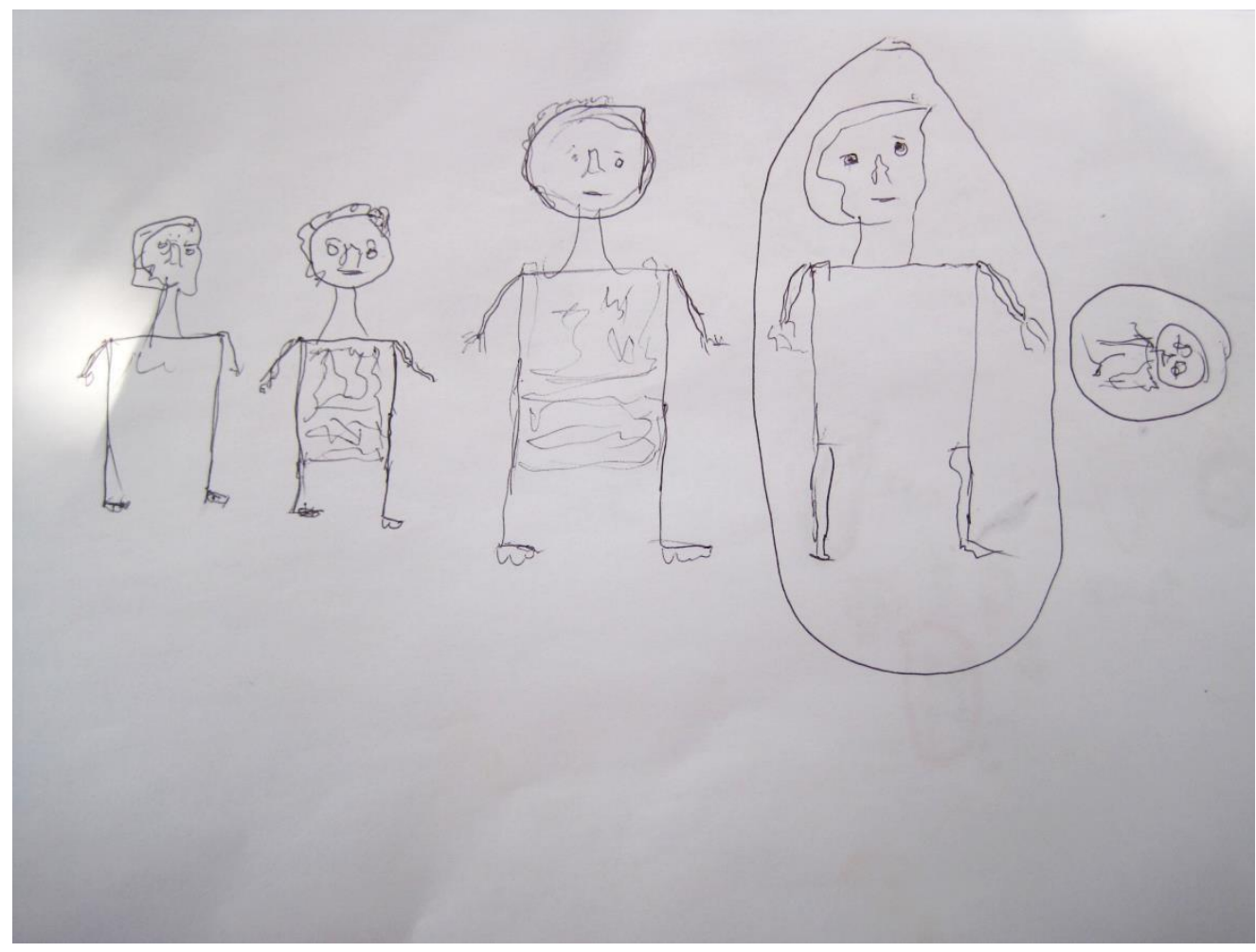

Figure 1: Female Participant's Household Diagram. Ashanti Region, Ghana 


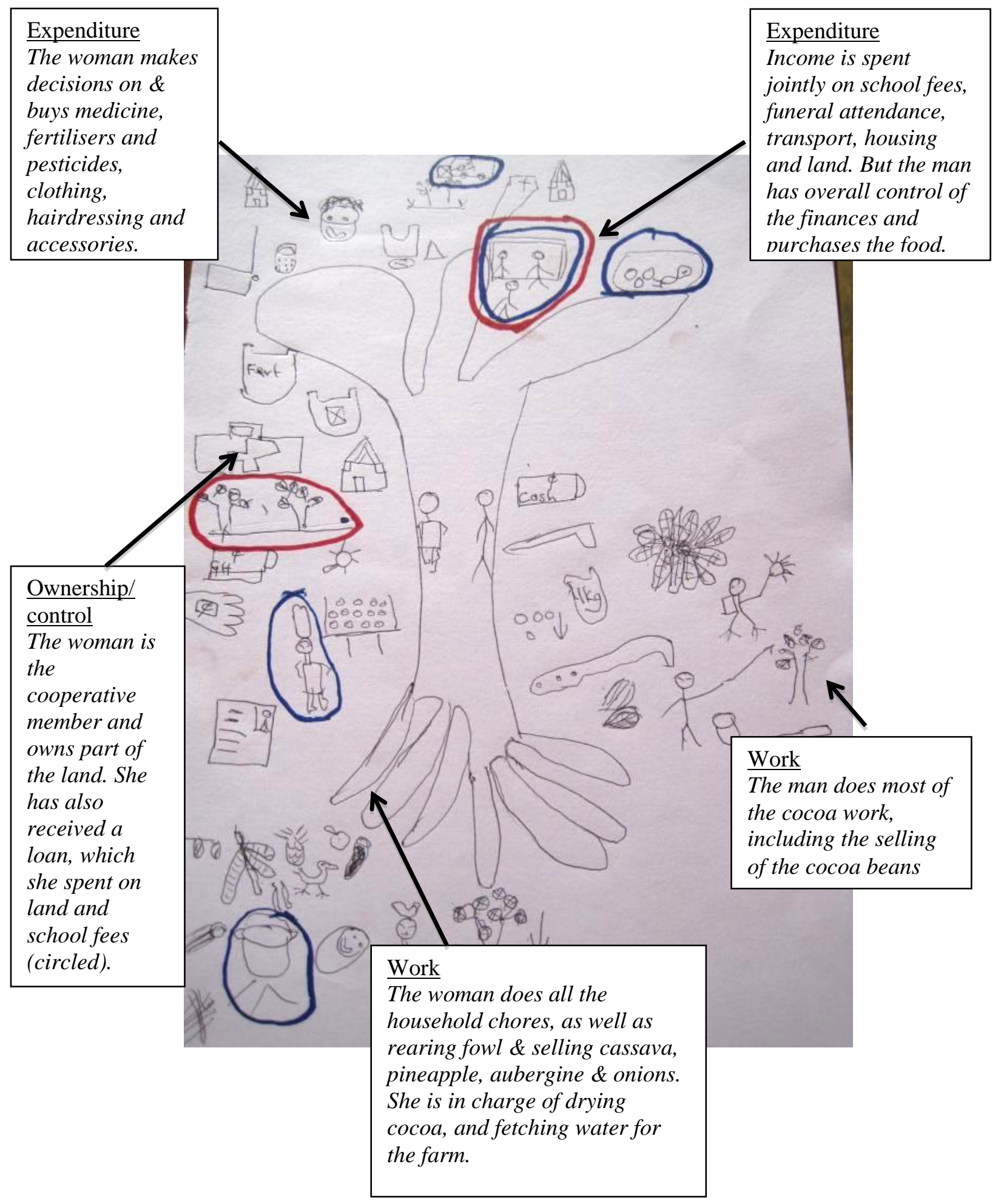

Figure 2: Gender Tree and summary explanations. Drawn by Female Participant in Western Region,

Ghana. 


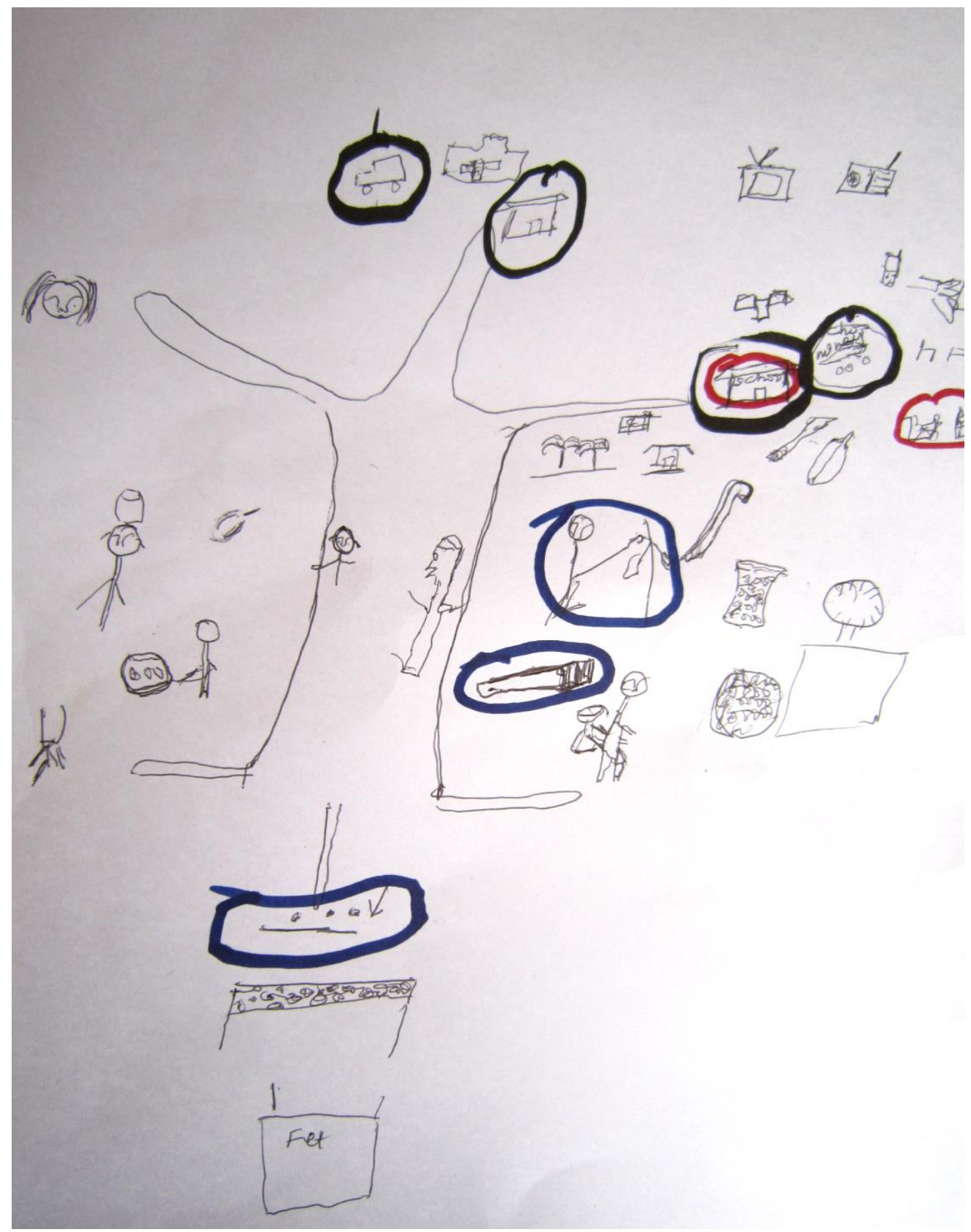

\section{Figure 3: Male Farmer's Gender Tree Diagram, Western Region, Ghana.}

This farmer owns the land, housing and money. He only lists cooking, carrying water, growing aubergine and carrying firewood as women's work (bottom left). Shared tasks are planting, drying and fertilising cocoa (middle under trunk). His work (right side) comprises of clearing and weeding land; carrying, harvesting, bagging, weighing and selling cocoa. He lists the only female expenditure decisions to be regarding haircuts. In terms of time use, he circles planting, harvesting and weeding as the most timeconsuming tasks for the household. 


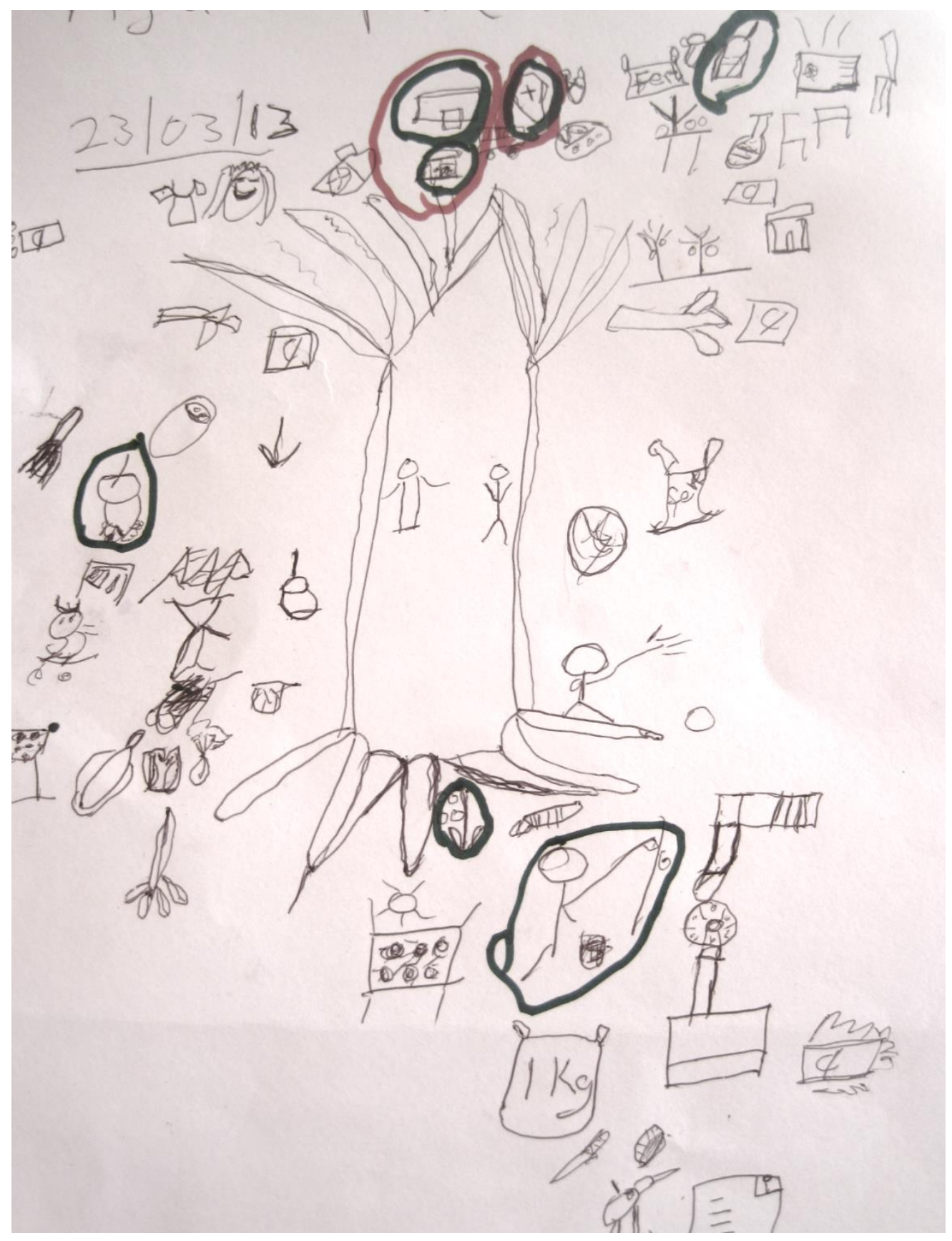

\section{Figure 4: Female Farmer's Gender Tree, Western Region, Ghana.}

In contrast to her husband's tree, the woman lists much more work on her (left-hand) side, including the growing and selling of bananas, aubergine, cassava and onions. She also processes gari for extra income, as well as contributing to the drying and planting of cocoa. She lists cooking, laundry, sweeping, carrying water and childcare. The husband's work (right side) is cocoa-farming heavy, but she also notes 'work' he has missed off: such as caring for fowl. Again, her only expenditure control is on hairdressing, and her clothing. She agrees that harvesting and planting take up time, but adds that in her experience cooking takes up the most time (circled, left). 


\begin{tabular}{|c|c|c|c|c|}
\hline Steps & Researcher tasks & Participant tasks & Form of Data Co-Created & Reflections on process \\
\hline $\begin{array}{l}\text { Before } \\
\text { workshop }\end{array}$ & $\begin{array}{l}\text { Prepare symbols } \\
\text { (Appendix 3) \& test them } \\
\text { with local staff. Practice } \\
\text { explanation of symbols \& } \\
\text { terms for locale. }\end{array}$ & - & $\begin{array}{l}\text { Symbols depict work tasks and } \\
\text { items purchased or owned. In } \\
\text { this case they were pre- } \\
\text { determined with local staff, } \\
\text { NGO staff and academic } \\
\text { researchers. Participants in the } \\
\text { field were then encouraged to } \\
\text { design and include their own } \\
\text { symbols whenever they } \\
\text { wished. }\end{array}$ & $\begin{array}{l}\text { Depending on level of familiarity with a pen, } \\
\text { participants could design their own symbols. In } \\
\text { conversation with the NGO who had } \\
\text { experience in Ghana, it was decided that pre- } \\
\text { prepared symbols would aid participants to } \\
\text { contribute. In other contexts with high non- } \\
\text { literacy a completely open design process had } \\
\text { overwhelmed participants. }\end{array}$ \\
\hline $\begin{array}{l}\text { During } \\
\text { Workshop } \\
1\end{array}$ & $\begin{array}{l}\text { Show participants } \\
\text { example of household } \\
\text { drawing; ask them to } \\
\text { draw their own \& circle } \\
\text { primary decision-maker. } \\
\text { Go round group and } \\
\text { clarify/help where } \\
\text { necessary. }\end{array}$ & $\begin{array}{l}\text { Each draws own } \\
\text { household } \\
\text { drawing } \\
\text { independently. }\end{array}$ & $\begin{array}{l}\text { Visual record of household, } \\
\text { including number of } \\
\text { dependent adults, children \& } \\
\text { key decision maker. Sex of } \\
\text { inhabitants discernible in } \\
\text { drawings (through clothing). } \\
\text { Captured through photograph } \\
\text { of original drawing. }\end{array}$ & $\begin{array}{l}\text { In Ghana many adults may live together but not } \\
\text { necessarily be dependent. With help from the } \\
\text { local staff we decided that asking to draw } \\
\text { 'those that eat from the same pot' enabled us to } \\
\text { see household units which shared resources. } \\
\text { This drawing was also useful for helping } \\
\text { participants relax and feel at ease with drawing, } \\
\text { and enabled the discussion to begin. }\end{array}$ \\
\hline 2 & $\begin{array}{l}\text { Draw 'gender tree' } \\
\text { outline. Fill in with own } \\
\text { symbols, encourage } \\
\text { participants to draw \& } \\
\text { create own symbols } \\
\text { where necessary. Use } \\
\text { humour to provoke } \\
\text { discussion \& enable } \\
\text { differences to emerge in } \\
\text { participants' own images. }\end{array}$ & $\begin{array}{l}\text { Each draws own } \\
\text { gender tree and } \\
\text { uses prepared } \\
\text { symbols or creates } \\
\text { own. }\end{array}$ & $\begin{array}{l}\text { Visual depiction of work done } \\
\text { by men, women \& shared. } \\
\text { Record of expenditure, \& who } \\
\text { makes decisions. Record of } \\
\text { land, housing, banking \& } \\
\text { loans ownership. Captured } \\
\text { through photograph of original } \\
\text { drawing. }\end{array}$ & $\begin{array}{l}\text { There are problems with doing research in } \\
\text { group settings. 1/ It was difficult at first to } \\
\text { impress upon participants that they should } \\
\text { draw their own unique trees - not their } \\
\text { neighbours or the researcher's. 2/ It was also } \\
\text { chaotic at times, trying to lead the group and } \\
\text { also take time to make sure each participant } \\
\text { was comfortable and understood the tasks. } \\
\text { However, the group setting was comforting to } \\
\text { participants, especially women, who felt more } \\
\text { able to speak about their drawings collectively. } \\
\text { Of course, it was also quicker, which was } \\
\text { beneficial for the researchers and for } \\
\text { participants, who had to return to their farms. } \\
\text { On the other hand, we needed to be mindful of }\end{array}$ \\
\hline
\end{tabular}




\begin{tabular}{|c|c|c|c|c|}
\hline & & & & $\begin{array}{l}\text { group dynamics when analysing the data (see } \\
\text { Appendix 2). }\end{array}$ \\
\hline 3 & $\begin{array}{l}\text { Call for a } 20 \text { minute } \\
\text { break. Hand out water and } \\
\text { snacks. }\end{array}$ & Break & - & $\begin{array}{l}\text { It was important to have a break with food } \\
\text { since the workshop is long, and many farmers } \\
\text { will have travelled since early in the morning } \\
\text { to get to the workshop site. Many mothers need } \\
\text { time to attend to small children or breastfeed. }\end{array}$ \\
\hline 4 & $\begin{array}{l}\text { Same-sex facilitator } \\
\text { encourages discussion in } \\
\text { same-sex groups, based } \\
\text { on overview questions. }\end{array}$ & $\begin{array}{l}\text { Discuss trees in } \\
\text { same-sex groups. }\end{array}$ & $\begin{array}{l}\text { Verbal focus group discussion, } \\
\text { captured through video } \\
\text { cameras. }\end{array}$ & $\begin{array}{l}\text { Same-sex groups were necessary in order to } \\
\text { break down some of the power relations } \\
\text { between men and women, and allow both } \\
\text { groups to be more open about their } \\
\text { experiences. We saw this in the ways in which } \\
\text { men opened up about adultery (see Appendix } \\
\text { 2) \& women shared worries over nutrition } \\
\text { which they may not have done in plenary. }\end{array}$ \\
\hline 5 & $\begin{array}{l}\text { Facilitator hosts whole } \\
\text { group discussion. }\end{array}$ & $\begin{array}{l}\text { Groups feedback } \\
\text { to each other } \\
\text { about what they } \\
\text { have learnt in the } \\
\text { workshop. }\end{array}$ & $\begin{array}{l}\text { Verbal focus group } \\
\text { discussions, captured by video } \\
\text { camera \& note-taking. }\end{array}$ & $\begin{array}{l}\text { At times, it became clear that some topics were } \\
\text { not being discussed in plenary (e.g. adultery). } \\
\text { We also had a problem in workshop } 4 \text { with a } \\
\text { particular man who tried to dominate the } \\
\text { discussion. It was useful then to have local } \\
\text { staff on hand to explain why we needed to hear } \\
\text { from others also, and to deal with it in a } \\
\text { humorous, locally appropriate manner. } \\
\text { We also tried to make the sessions inclusive by } \\
\text { always encouraging the 'least' powerful to } \\
\text { comment first, and by ensuring everyone has } \\
\text { their say in the process (e.g. Mayoux, 2010). }\end{array}$ \\
\hline 6 & $\begin{array}{l}\text { End workshop. Take final } \\
\text { photos; give thanks to } \\
\text { participants and to local } \\
\text { chief or other community } \\
\text { members, in line with } \\
\text { local customs. }\end{array}$ & $\begin{array}{l}\text { Participants keep } \\
\text { all drawings. }\end{array}$ & - & $\begin{array}{l}\text { It was important to remind participants that } \\
\text { participation did not result in any benefits from } \\
\text { the supplier company. They did ask for help, } \\
\text { but we had to be clear that we could make no } \\
\text { promises on their behalf. We could, however, } \\
\text { pass on their concerns. }\end{array}$ \\
\hline
\end{tabular}

Appendix 1: Research Process with reflections on GALS Case Study, Ghana. 


\begin{tabular}{|c|c|c|c|}
\hline$\underline{\text { Step }}$ & $\underline{\text { Process }}$ & $\begin{array}{l}\text { Form of Data } \\
\text { Co-Constructed }\end{array}$ & $\underline{\text { Reflection on Process }}$ \\
\hline 1 & $\begin{array}{l}\text { Follow-up interviews with supplier staff } \\
\text { present at workshops. } \\
\text { Immediately after each workshop reflect on } \\
\text { process with suggestions for improvements. }\end{array}$ & $\begin{array}{l}\text { Qualitative } \\
\text { verbal data. }\end{array}$ & $\begin{array}{l}\text { It was really eye-opening to hear from local staff what their } \\
\text { impressions of the workshops were. In the first workshop they } \\
\text { were able to point out to us that the men had been reticent about } \\
\text { adding expenditure such as drinking, gambling or mistresses, } \\
\text { since the groups were mixed. We were then able to address this } \\
\text { in subsequent workshops by acknowledging this in the single- } \\
\text { sex portion of the discussion. } \\
\text { The presence of some staff at the workshop, however, needed to } \\
\text { be taken into consideration in terms of analysis. We could see } \\
\text { that they skewed some verbal responses, in that participants } \\
\text { used the workshops to ask for resources from the suppliers. } \\
\text { Author One also had to remind certain staff, at times, that they } \\
\text { were not allowed to draw on behalf of participants. However, } \\
\text { without them there we would have struggled to organise and } \\
\text { implement the workshops, given language and cultural } \\
\text { differences. }\end{array}$ \\
\hline 2 & $\begin{array}{l}\text { Keep ongoing research diary. Use these notes } \\
\text { to reflect on process and complement videos } \\
\text { and photographs of the workshops with own } \\
\text { personal reflections. }\end{array}$ & N/A & $\begin{array}{l}\text { Personal reflections and observations noted during the field } \\
\text { work were very useful for remembering events and problems. } \\
\text { The diary wasn't analysed as data, but formed a useful prompt } \\
\text { during the analysis of other data. }\end{array}$ \\
\hline 3 & $\begin{array}{l}\text { Analysis of drawings. } \\
\text { Photos of the images and videos were } \\
\text { uploaded into the NVivo10 media function. } \\
\text { Household drawings were descriptively } \\
\text { analysed (e.g. how many women were } \\
\text { decision-makers; how many children were in } \\
\text { each household on average). } \\
\text { The trees were analysed using a form of }\end{array}$ & $\begin{array}{l}\text { Quantitative } \\
\text { data on } \\
\text { household } \\
\text { dynamics \& the } \\
\text { gendered } \\
\text { division of } \\
\text { labour in cocoa } \\
\text { farming. }\end{array}$ & $\begin{array}{l}\text { We had to consider whether participants had drawn their own } \\
\text { experiences or had copied from each other, or the facilitator. } \\
\text { We checked for this in situ as best we could, but also had to } \\
\text { reflect on this in the analysis process. } \\
\text { We were worried whether participants' low level of schooling } \\
\text { would result in indecipherable images. Yet only one drawing } \\
\text { out of forty-eight was completely indecipherable. }\end{array}$ \\
\hline
\end{tabular}




\begin{tabular}{|c|c|c|c|}
\hline & $\begin{array}{l}\text { visual content analysis. Using the symbol key } \\
\text { (Appendix 3) as a discrete matrix (Bell, } \\
\text { 2001), the trees were coded for different } \\
\text { work, expenditure \& ownership by gender } \\
\text { into an SPSS spreadsheet. This meant } \\
\text { 'attaching a set of descriptive labels' (Rose, } \\
2012 \text {, p.90) which were exhaustive (i.e. all } \\
\text { symbols were counted and coded) and } \\
\text { exclusive (each symbol related to only one } \\
\text { label) (Rose, 2012). We ran simple } \\
\text { descriptive analytics to produce frequencies } \\
\text { and correlations. }\end{array}$ & & $\begin{array}{l}\text { Triangulation with other methods (see below) and existing } \\
\text { studies (e.g. Barrientos, 2014) helps to highlight inconsistencies } \\
\text { and achieve validity. The drawing, however, is the main data } \\
\text { source so takes precedence if there are no conflicts with verbal } \\
\text { data. } \\
\text { It greatly helped to present the initial analysis to the NGO } \\
\text { partner who was able to give feedback for a second round of } \\
\text { coding. }\end{array}$ \\
\hline 4 & $\begin{array}{l}\text { Analysis of verbal data. } \\
\text { Verbal data was drawn from videos recorded } \\
\text { at the workshops, and from the conversations } \\
\text { in step } 1 \text { and interviews in step } 4 \text {. Videos } \\
\text { were re-watched and key points transcribed. } \\
\text { The text was uploaded into NVivo10. This } \\
\text { enabled us to use the same codes from visual } \\
\text { data with verbal data (i.e. women do not own } \\
\text { land). Other codes were developed } \\
\text { thematically, in line with the Gioia et al. } \\
\text { (2013) method. }\end{array}$ & $\begin{array}{l}\text { Qualitative data } \\
\text { on gendered } \\
\text { divisions of } \\
\text { labour \& men } \\
\text { and women's } \\
\text { responses to } \\
\text { this. }\end{array}$ & $\begin{array}{l}\text { Analysing the verbal data on videos showed us how difficult it } \\
\text { had been using a translator. It would have been preferable if one } \\
\text { of the lead researchers had spoken the local language, since it } \\
\text { became clear that at times the translator had mis-communicated } \\
\text { between us and the participants. } \\
\text { This is a limitation of using a translator in any qualitative } \\
\text { research. However, we privileged the drawings as our main data } \\
\text { source, and this gave us a more direct form of communication } \\
\text { with the farmers themselves and helped with the credibility of } \\
\text { the findings. }\end{array}$ \\
\hline 5 & $\begin{array}{l}\text { Follow up conversations with NGO and } \\
\text { Supplier staff (largely by email). }\end{array}$ & $\begin{array}{l}\text { Qualitative } \\
\text { verbal data }\end{array}$ & $\begin{array}{l}\text { Enabled updates on the outcomes of the research evaluation to } \\
\text { shape how we evaluated the use of GALS itself. }\end{array}$ \\
\hline
\end{tabular}

Appendix 2: Analysis Process with Reflection, GALS Case Study, Ghana. 


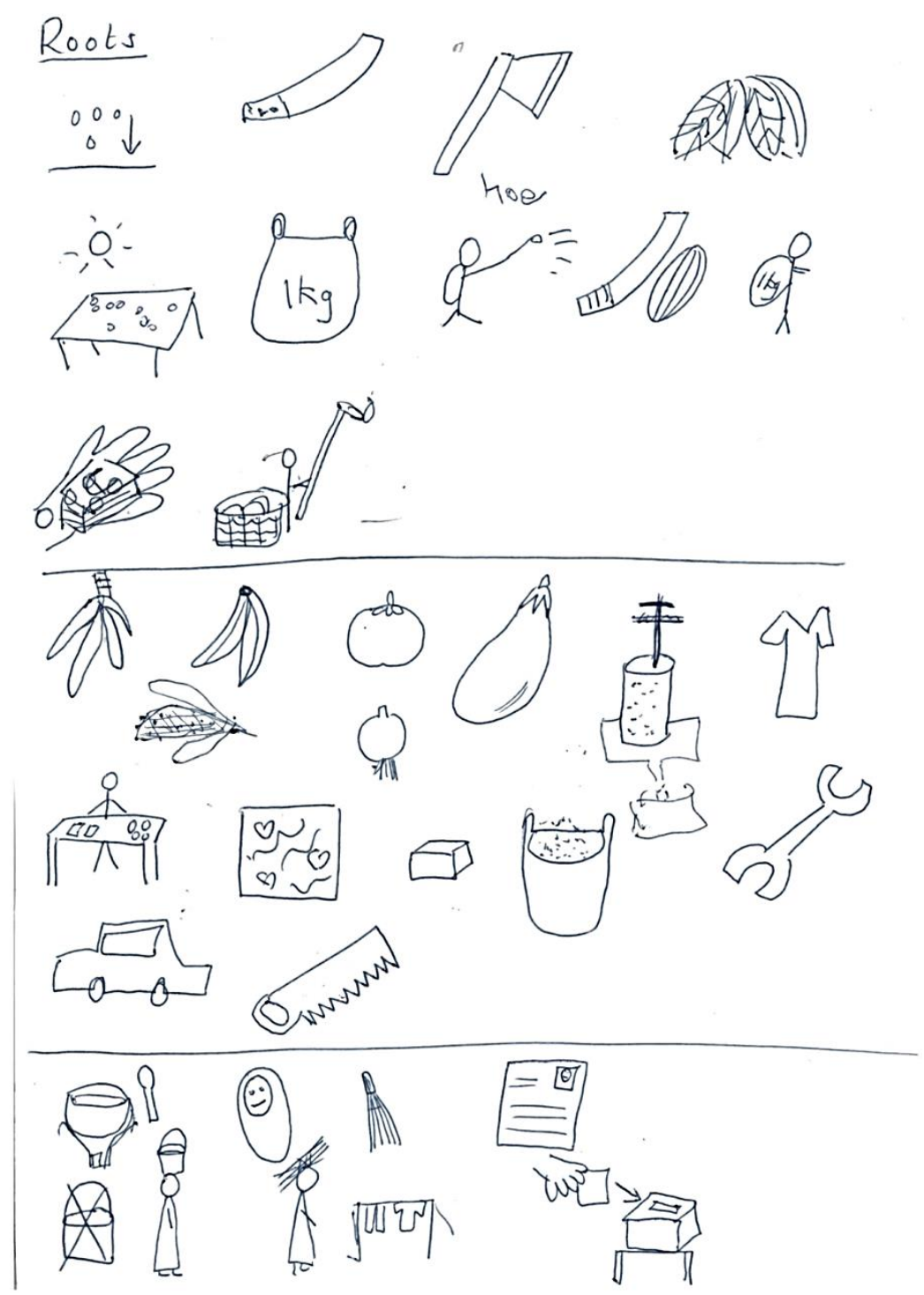

Appendix 3: Example of Symbols Co-created between Researchers and Local Staff.

\section{From top left- to right, symbols represent work including:}

Cocoa Work: Planting cocoa seeds; weeding; clearing land; fermenting; drying; bagging; fertilising/spraying pesticides; cutting open pods; carrying cocoa; selling; harvesting.

Other Income: Growing cassava, bananas/plantain, tomatoes, aubergine; palm oil processing; tailoring; trading small goods; growing maize, onions; batik making; soap making; gari processing; mechanic; taxi driving; carpentry.

Unpaid Work: Cooking; childcare; sweeping; cooperative membership; carrying water; carrying firewood; washing \& drying clothes; cooperative committee membership position. 
Notes

${ }^{1}$ There are many different forms and terminologies attached to participatory research. Many fall under the term Participatory Action Research (PAR) which entails the researcher being actively involved in bringing about some sort of social or organisational change (Reason, 1994).

Narayanasamy (2009) lists over 24 different terms. Not all of these will include visual methods or approaches, but many do so. Equally, visual methodologies are numerous, but vary in their degree of participation (Vince \& Broussine, 1996; Warren, 2005). 